\title{
Interleukin 1 is a key driver of inflammatory bowel disease- demonstration in a murine IL-1Ra knockout model
}

\author{
Rasha H. Dosh ${ }^{1,3}$, Nicola Jordan-Mahy ${ }^{1}$, Christopher Sammon ${ }^{2}$ and Christine Le \\ Maitre' \\ ${ }^{1}$ Biomolecular Sciences Research Centre, Sheffield Hallam University, Sheffield, UK \\ ${ }^{2}$ Materials and Engineering Research Institute, Sheffield Hallam University, Sheffield, UK \\ ${ }^{3}$ Department of Anatomy and Histology, Faculty of Medicine, University of Kufa, Kufa, Iraq \\ Correspondence to: Christine Le Maitre, email: c.lemaitre@shu.ac.uk \\ Keywords: IL-1Ra deficient; inflammatory bowel disease; pro-inflammatory cytokines; matrix-degrading enzymes; intestinal enzymes \\ Received: October 23, $2018 \quad$ Accepted: April 03, $2019 \quad$ Published: May 28, 2019 \\ Copyright: Dosh et al. This is an open-access article distributed under the terms of the Creative Commons Attribution License 3.0 \\ (CC BY 3.0), which permits unrestricted use, distribution, and reproduction in any medium, provided the original author and source \\ are credited.
}

\section{ABSTRACT}

Interleukin 1 (IL-1) is an important mediator of inflammation and tissue damage in inflammatory bowel disease (IBD). The balance between IL-1 and IL-1Ra as a natural inhibitor plays a vital role in a variety of diseases. Here, we investigated whether changes seen during IBD are induced spontaneously in mice lacking a functional $I L-$ 1 rn gene. Histological staining was performed on the jejunum and ileum of BALB/C $I L-1 \mathrm{rn}^{+/+}$and $I L-1 \mathrm{rn}^{-/-}$mice to characterize crypt-villus height, villus width, and number of goblet cells per villus. Pro-inflammatory cytokines, immune cell infiltration and matrix-degrading enzymes, together with the production of intestinal enzymes and the integrity of tight and adherent junction proteins were determined using immunohistochemistry. In the small intestine of BALB/c IL-1 rn ${ }^{-/-}$mice the villus heights were significantly reduced; and in the ileum this was accompanied by a decrease in villi width. There was also an increase in goblet cell number and mucin production compared to wild-type mice. IL-1a and IL-1 $\beta$ immunopositivity were increased, whilst IL-1R1 expression was decreased in $I L-1 \mathrm{rn}^{-/-}$mice. IL-15 and TNFa were also increased in older $I L-1 \mathrm{rn}^{-/-}$mice. Increased polymorphonuclear and macrophage infiltration were seen in $I L-1 \mathrm{rn}^{-/-}$mice, whilst expression of matrix-degrading enzymes and digestive enzymes were unchanged, except for dipeptidyl peptidase IV which was increased in younger $I L-1 \mathrm{rn}^{-/-}$mice compared to wild type mice. The expression of tight and adhesion junctions were also dramatically decreased in $I L-1 \mathrm{rn}^{-/-}$mice. In conclusion, $I L-$ $1 \mathrm{rn}^{-/-}$mice developed spontaneous abnormalities which displayed features associated with IBD, demonstrating a clear role for IL-1 in IBD.

\section{INTRODUCTION}

Inflammatory bowel disease (IBD) is a chronic autoimmune disease characterised by inflammation of the gastrointestinal tract and can be divided into two main types. Crohn's disease (CD), which affects any part of the gastrointestinal tract especially the terminal ileum and colon; and ulcerative colitis (UC) which affects the rectum and colon [1]. Although the pathogenesis of IBD is not fully understood, IBD is thought to be caused by an imbalance between pro- and anti-inflammatory cytokines in local tissues which leads to inflammation and malfunction of the barriers in the intestinal tissue.

Interleukin 1 (IL-1) is a key mediator of innate immunity and inflammation which results in tissue damage in IBD. An imbalance between IL-1 and IL1 Ra has been shown in the inflamed mucosa of patients with IBD where the levels of IL-1 and IL-Ra were increased, but importantly the ratio of IL-1Ra to IL-1 was significantly decreased compared with controls 
$[1,2]$. During Crohn's disease, IL- $1 \beta$ is significantly raised and there is a positive correlation between the severity of mucosal inflammation and the levels of IL-1 $\beta$ [3]. It can also result in apoptosis of epithelial cells causing tissue damage and barrier dysfunction. Subsequently, the role of IL-1 Ra in disease progression has been studied in various experimental animal models of IBD [4-6].

In the SAMP/YiT experimental mice model, there was an increase in Th-1 activity which mediates intestinal inflammation, and there was a spontaneous appearance of chronic ileitis which was similar in appearance to Crohn's disease due to increased intestinal paracellular permeability $[7,8]$. This chronic ileitis is characterised by intestinal inflammation, having mononuclear and polymorphonuclear infiltration of the lamina propria; plus hyperplasia of paneth and goblet cells [9].

Although studies have reported that an imbalance between IL-1 and IL-1Ra contributes to inflammation in the large intestine in patients of IBD and in experimental animal models $[1,10,11]$, whether this is a causative factor is unclear. Here, the histological changes in the small intestine of IL-1Ra knockout mice were investigated to assess the expression of pro-inflammatory cytokines, infiltration of immune cells, matrix-degrading enzymes, junctional proteins, and digestive enzymes in the small intestine of IL1 Ra knockout mice compared to wild-type mice in two age groups in order to determine whether features associated with IBD could be induced spontaneously in the small intestine by the removal of IL-1Ra in mice.

\section{RESULTS}

\section{Histological analysis}

\section{Crypt-villus axis height and villus width}

In the jejunum, there was a significant decrease in height of crypt-villus axis of the 155-185 day old $I L-1 n^{-1}$ mice compared with age-matched WT mice $(\sim 7 \%$ decrease $)(\mathrm{P} \leq 0.05)$ (Figure 1). However, the cryptvillus height of the jejunum was significantly greater in the 155-185 day old compared to the 55-day old mice in WT groups $(\mathrm{P} \leq 0.05)$. The width of the villus at half crypt-villus axis was unchanged in all groups (Figure 1). Morphology of jejunal villi of 155-185 day old $I L-1 \mathrm{rn}^{-1}$ mice revealed moderate epithelial damage with separation of the columnar epithelia from the lamina propria within the villi and the formation of large spaces between the crypt base and the muscularis mucosa in the 55-day old $I L-1 \mathrm{rn}^{-/}$mice (Figure 1).

In the ileum, there was a significant decrease in the crypt-villus axis height of both the 55-day old ( $7 \%$ decrease) and 155-185 day old ( $13 \%$ decrease) $I L-1 \mathrm{rn}^{-1-}$ mice compared with WT mice $(\mathrm{P} \leq 0.05)$ and a significant decreased in 155-185 day old $I L-1 r n^{-\digamma}$ mice compared with 55 -day old $I L-1 r n^{-/}$mice $(\mathrm{P} \leq 0.05)$. In contrast, the crypt- villus axis height was significantly increased in 155-185 day old $I L-1 \mathrm{rn}^{+/+}$mice compared with 55-day $I L-1 \mathrm{rn}^{+/+}$ mice (Figure 2). A significant decrease was seen in villus width in 155-185 day old $I L-1 \mathrm{rn}^{-/}$mice compared with $155-185$ day old WT mice ( $\sim 15 \%$ decrease) and 55-day $I L$ $1 r n^{-/}$mice $(\mathrm{P} \leq 0.05)$. While villus width in the ileum was significantly increased in 155-185 day WT mice compared with 55-day old WT mice $(\mathrm{P} \leq 0.05)$ (Figure 2). Once again there was a separation of the columnar epithelium from the lamina propria within the villi and the formation of large spaces between the crypt base and the muscularis mucosa in the 155-185 day old $I L-1 r n^{-/}$mice (Figure 2).

\section{Number of goblet cells per crypt-villus axis}

In the jejunum and ileum, there was a significant increase in the number of goblet cells per crypt-villus axis in all $I L-1 r n^{-1}$ mice groups compared with WT mice $(\mathrm{P} \leq 0.05)$. Furthermore, in the jejunum, there was a significant increase in the number of goblet cells per cryptvillus axis in 155-185 day old WT compared to 55 day old WT mice $(\mathrm{P} \leq 0.05)$ (Figure $3 \mathrm{~A} \& 3 \mathrm{~B})$. Moderate and intense PAS (pink) staining was observed in 55 day old WT and $\mathrm{IL}-1 \mathrm{rn}^{-1}$ mice and intense alcian blue staining was observed in 155-185 day old WT and $I L-1 \mathrm{rn}^{-1}$ mice. This indicated the presence of neutral mucins in younger mice, and acidic mucins in older mice in both the jejunum and the ileum (Figure 3A \& 3B).

\section{Assessment of pro-inflammatory cytokine expression and localization}

Across the small intestine (jejunum and ileum), the expression of pro-inflammatory cytokine: IL-1 $\alpha$ was highly expressed in both the villi and crypts. There was a significant increase in IL- $1 \alpha$ immunopositivity in 155185 day old $I L-1 r n^{-/}$mice, compared with WT mice and 55 day $I L-1 r n^{-/}$mice $(\mathrm{P} \leq 0.05)$ (Supplementary Figure $1 \mathrm{~A}$ and Figure 4A \& 4B). Whilst high levels of IL-1 $\alpha$ were seen in all mice, only low levels of immunopositivity were seen in WT mice with a significant increase in IL-1 $\beta$ in the 55 day old and 155-185 day old $I L-1 r n^{-/}$mice, compared with WT mice $(\mathrm{P} \leq 0.05)$ (Supplementary Figure 1B and Figure 4C \& 4D). The expression of IL-1R1 was primarily located in villi (Supplementary Figure $1 \mathrm{C}$ and Figure 4E \& $4 \mathrm{~F}$ ); however, there was a significant decrease in IL$1 \mathrm{R} 1$ expression in both the 55 day old and 155-185 day old $I L-1 r n^{-}$mice compared with WT mice $(\mathrm{P} \leq 0.05)$. IL-1R1 expression in 155-185 day old WT and 155-185 day old $I L-1 r n^{-/}$mice were significantly lower than those seen in the 55 day old WT and 55 day old $I L-1 \mathrm{rn}^{-/}$mice, respectively $(\mathrm{P} \leq 0.05)$ (Supplementary Figure $1 \mathrm{C}$ and Figure 4E \& 4F).

IL-15 expression was observed only at low levels in the 55 day old $I L-1 \mathrm{rn}^{-/}$mice, and localized in both the villi and crypts, but significantly increased in the 155-185 day old $I L-1 r n^{-/}$mice, compared with WT mice $(\mathrm{P} \leq 0.05)$ (Supplementary Figure 2A and Figure 5A \& 5B). TNF $\alpha$ expression was also observed at low levels in the 55 day 
old $I L-1 r n^{-/}$mice. TNF $\alpha$ was localized in the villi of the jejunum and in the submucosa of the ileum, and was expressed at greater levels than in the WT mice. Whereas TNF $\alpha$ expression was significantly increased in the 155 185 day old $I L-1 r n^{-/}$mice, where immunopositive cells were localized within the villi, crypts, and the submucosa of the jejunum and ileum, and was significantly greater than that seen in the WT mice $(\mathrm{P} \leq 0.05)$ (Supplementary Figure 2A and Figure 5C \& 5D).

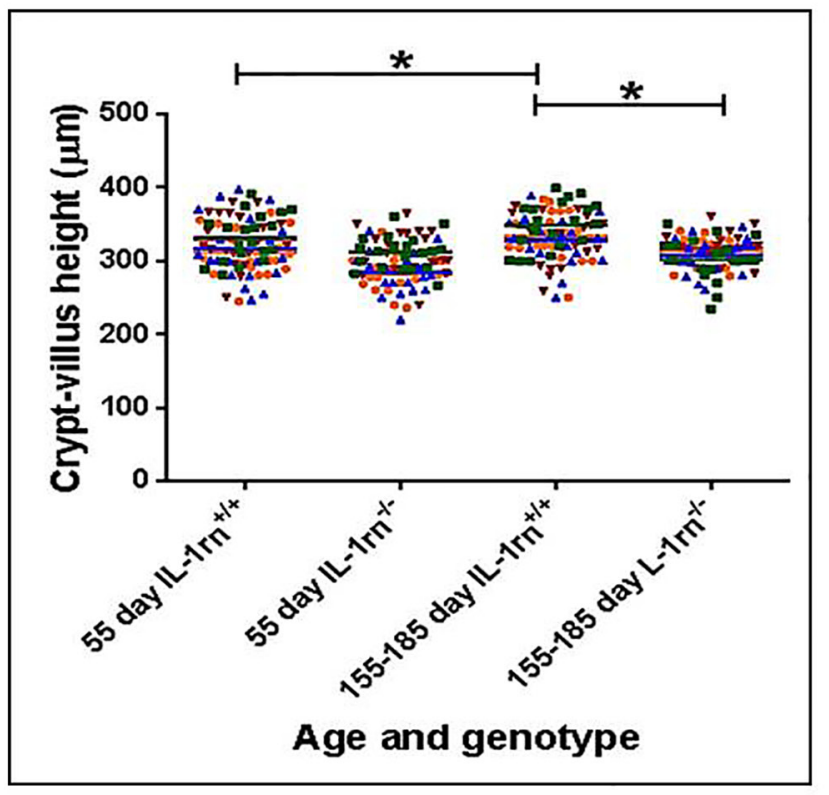

55 day $I L-1 r n^{+/+}$
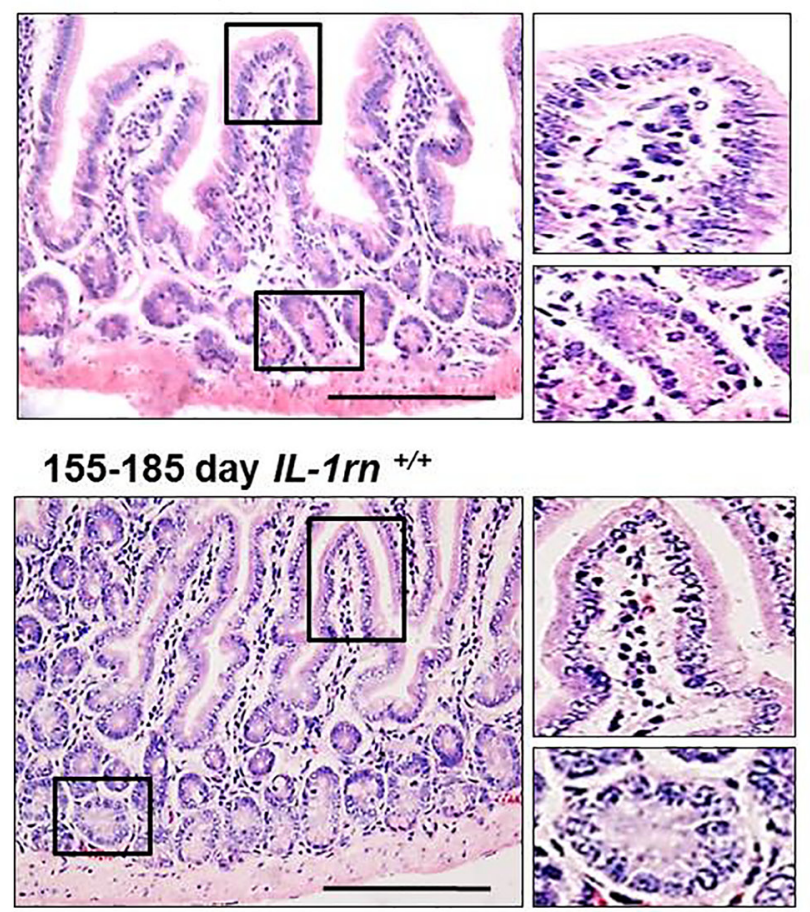

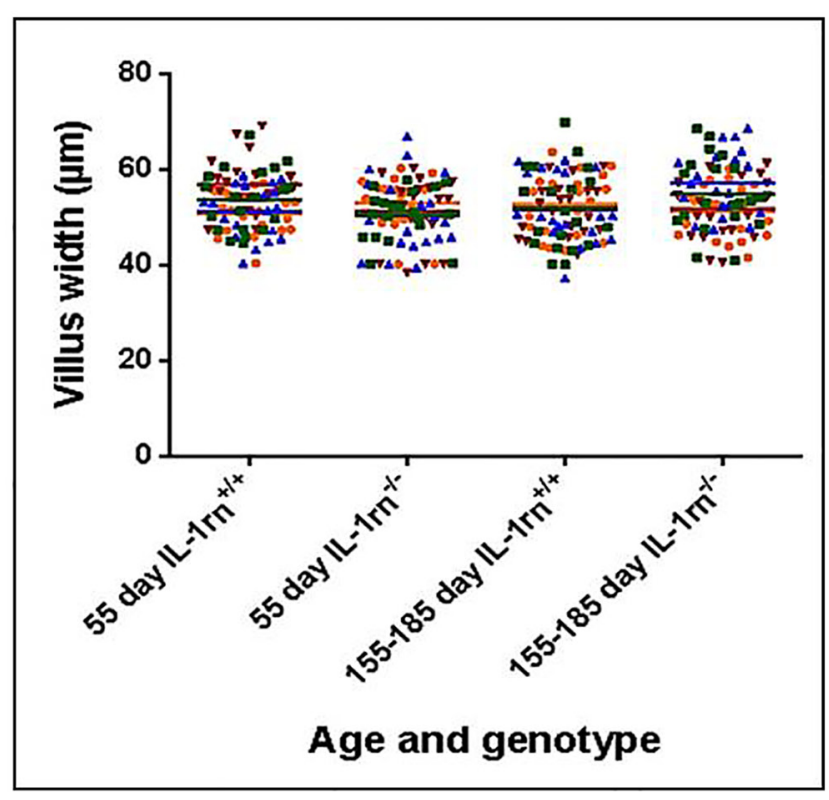

55 day IL-1rn $\%$

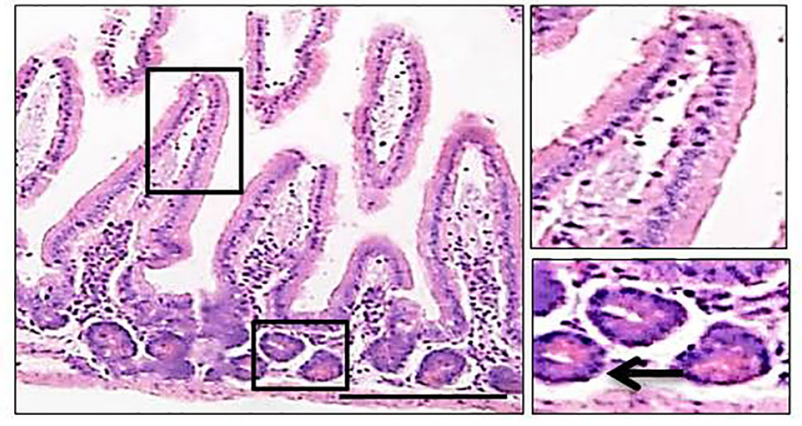

155-185 day IL-1rn $\%$
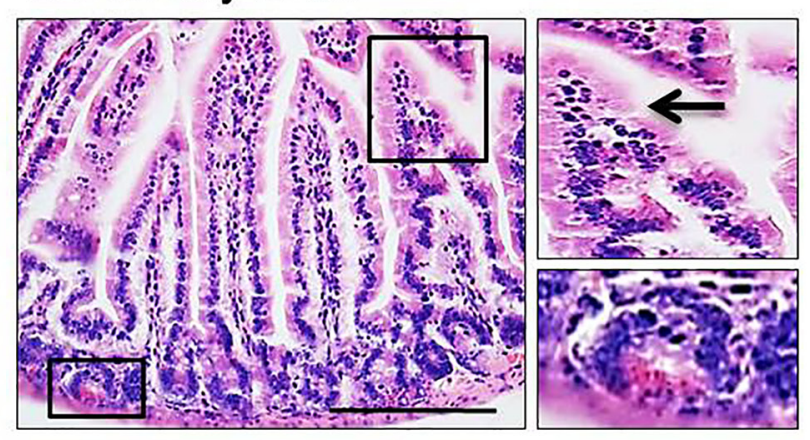

- Mouse $1 \Delta$ Mouse $2 \cdot$ Mouse $3 \cdot$ Mouse 4

Figure 1: Histological analysis and morphology of the intact well-oriented crypt-villus axis heights and villus widths of Jejunum in the 55 day old IL-1 $\mathrm{rn}^{-/}$mice and 155-185 day old IL-1 $\mathrm{rn}^{-/}$mice compared to age-matched wild-type mice. Stained with H\&E. Black arrows indicate moderate epithelial damage in 155-185 day old IL-1 $\mathrm{rn}^{-/}$mice, enlarged space between the crypt base and the muscularis mucosa. ${ }^{*} P \leq 0.05$. Scale bar $=100 \mu \mathrm{m}$. 
The number of infiltrated polymorphonuclear (PMN) cells in the lamina propria were significantly increased in the 55 day old and 155-185 day old
$I L-1 r n^{-/}$mice compared with WT mice $(\mathrm{P} \leq 0.05)$ (Supplementary Figure 3A and Figure 6A \& 6B). Crypt abscesses were observed in the ileum of 155-185 day
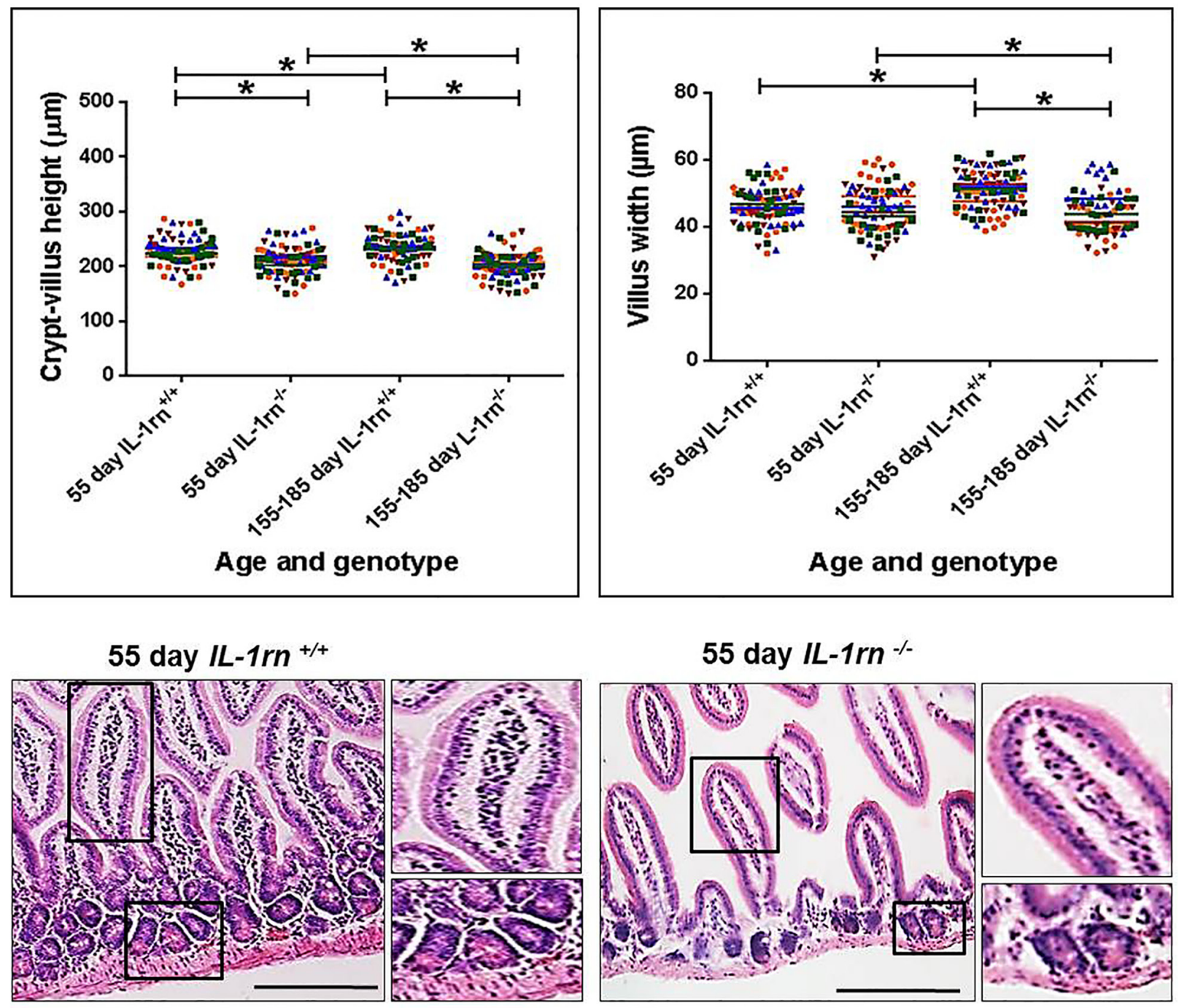

55 day $I L-1 r^{-1-}$

155-185 day IL-1rn ${ }^{+/+}$
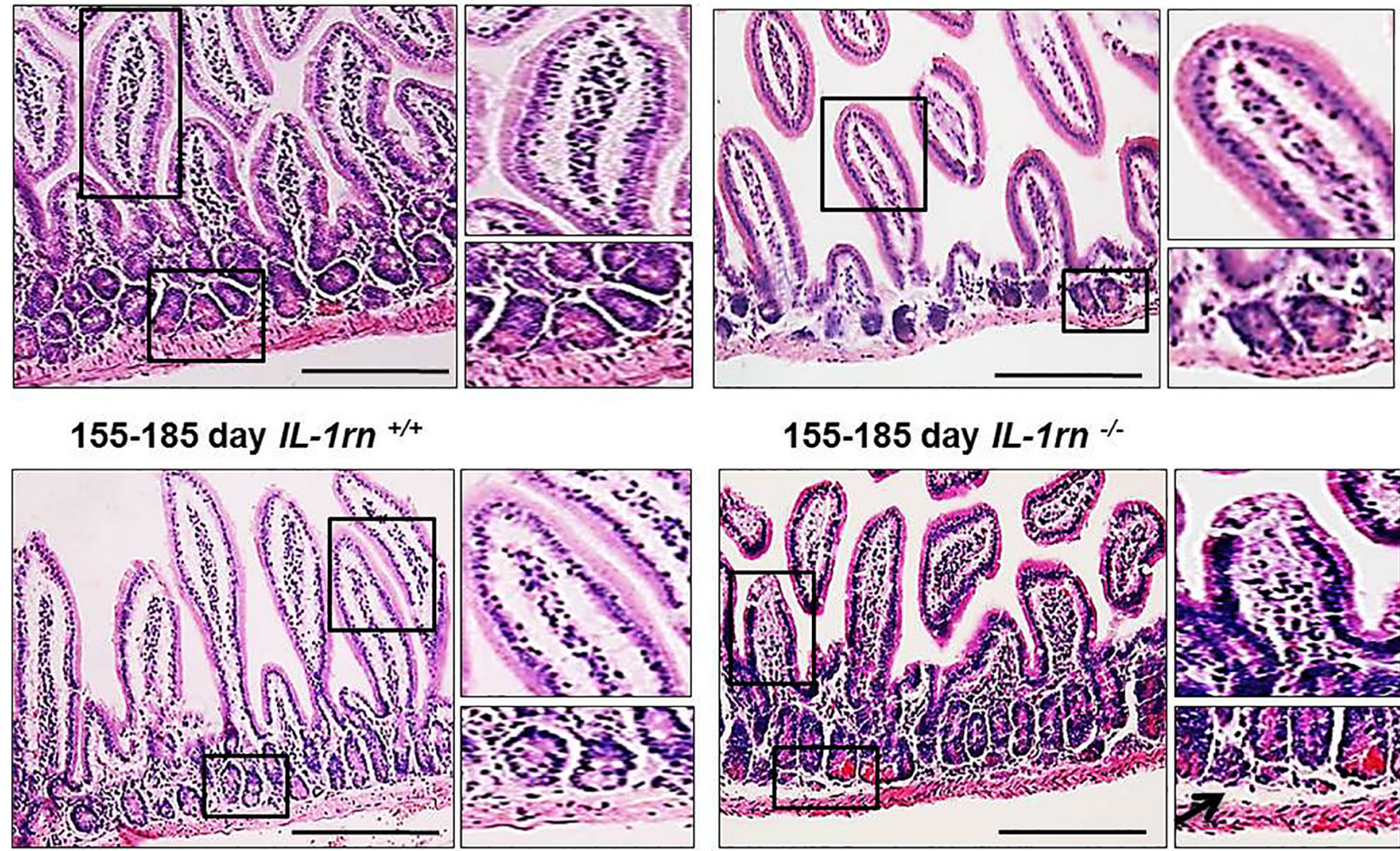

155-185 day $I L-1 r^{-/}$

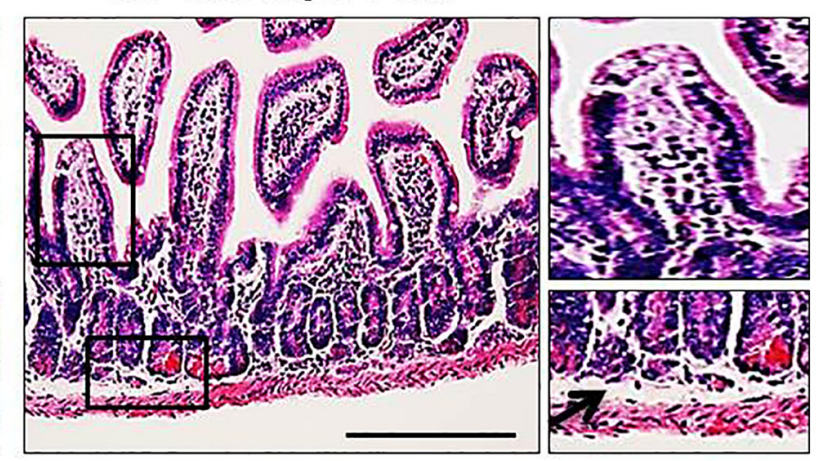

- Mouse $1 \Delta$ Mouse 2 - Mouse 3. Mouse 4

Figure 2: Histological analysis and morphology of the intact well-oriented crypt-villus axis heights and villus widths of Ileum in the 55 day old IL-1 rn ${ }^{-/}$mice and 155-185 day old IL-1 rn ${ }^{-/}$mice compared to age-matched wild-type mice. Stained with H\&E. Black arrows indicate enlarged space between the crypt base and the muscularis mucosa. ${ }^{*} P \leq 0.05$. Scale bar $=100 \mu \mathrm{m}$. 
old $I L-1 r n^{-/}$mice. Here, PMN cells were seen to cluster together within the lamina propria of the villi of 55 day old $I L-1 \mathrm{rn}^{-/}$mice and in the crypts of the 155-185 day old $I L-1 r n^{-/}$mice. The number of macrophages was significantly increased in 55 day old and 155-185 day old $I L-1 r n^{-/}$mice compared with WT mice $(\mathrm{P} \leq 0.05)$. Similar distributions were seen throughout the lamina propria of the villi in the young and old $I L-1 r n^{-/}$mice in the jejunum and ileum (Supplementary Figure $3 \mathrm{~B}$ and Figure 6C \& 6D).

\section{A Jejunum}

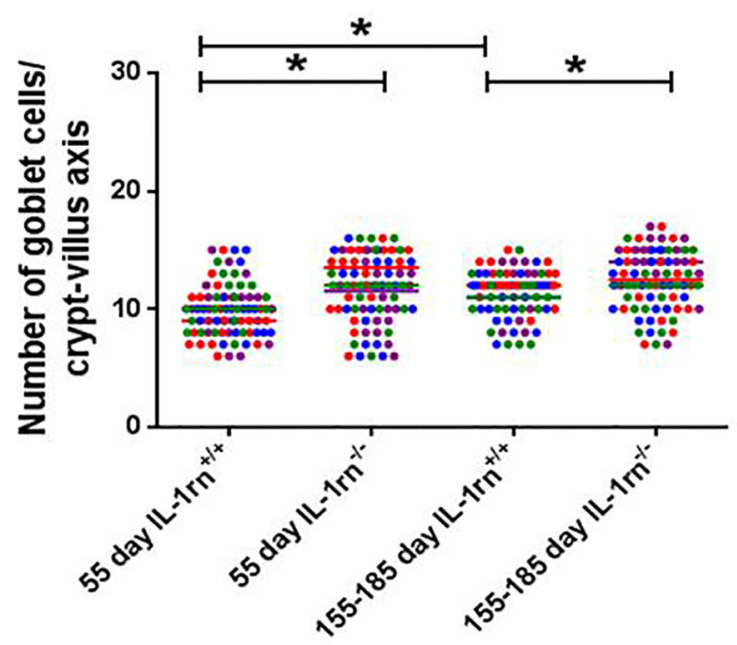

Age and genotype
55 day $I L-1 r n^{+/+}$

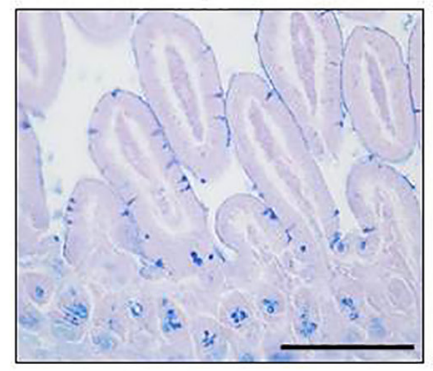

$155-185$ day $I L-1 r n^{+/+}$

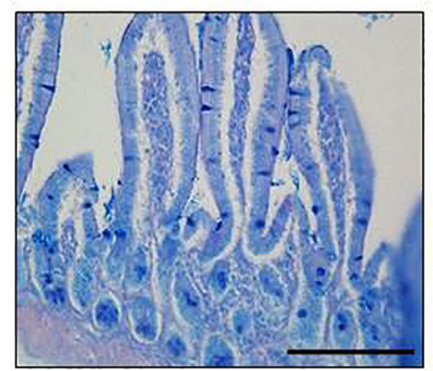

55 day $I L-1 r n^{+/+}$

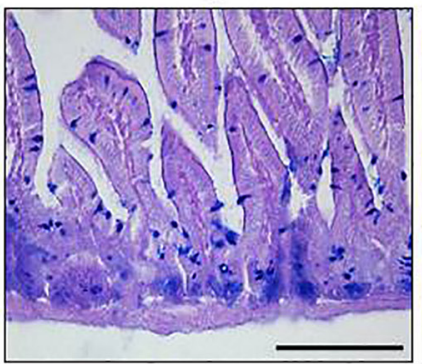

$155-185$ day $I L-1 r n^{+/+}$

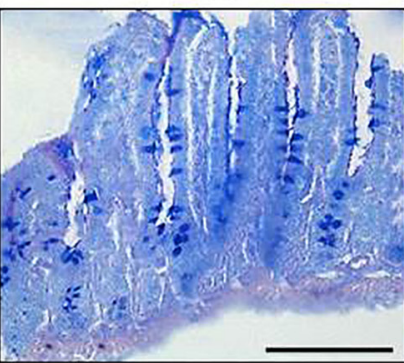

55 day $\mathrm{IL}-1 \mathrm{rn}{ }^{-1}$

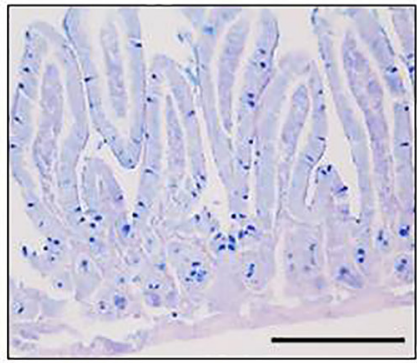

155-185 day $I L-1 r n \%$

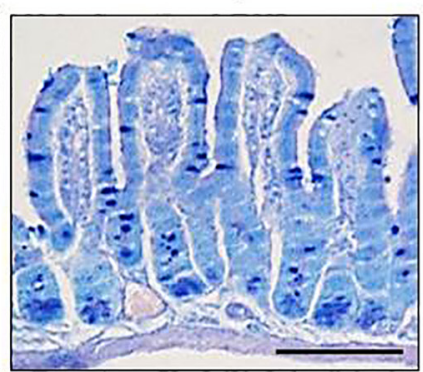

55 day $\mathbf{L}-1 \mathrm{rn} \%$

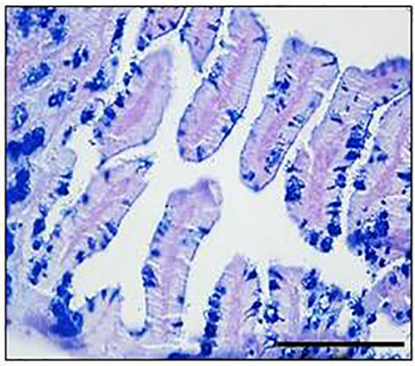

155-185 day IL-1rn $\%$

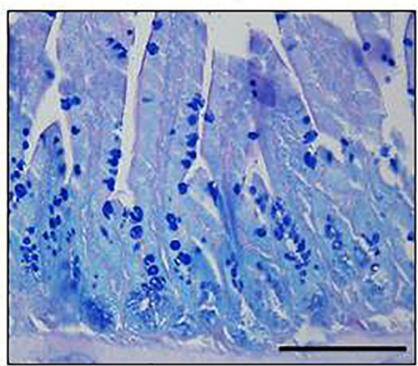

- Mouse 1 - Mouse 2 -Mouse $3 \bullet$ Mouse 4

Figure 3: Histological analysis and morphology of goblet cells per intact well-oriented crypt-villus axis of the (A) Jejunum and (B) Ileum of 55 day old and 155-185 days old IL-1 $\mathrm{rn}^{-/}$mice compared with age-matched WT mic, stained with AB-PAS. ${ }^{*} P \leq 0.05$. Scale bar $=100 \mu \mathrm{m}$. 
Assessment of degrading enzyme expression and localization

Although MMP2 expression was higher in both the 55 day old and $155-185$ day old $I L-1 r n^{-/}$mice than WT mice, this failed to reach significance. In 55 day old and 155-185 day old $I L-1 r n^{-/}$mice, MMP2 was highly expressed in the villi, crypts and muscularis mucosa (Supplementary Figure 4A and Figure 7A and 7B).

MMP9 expression was limited in all groups; its expression was higher in the submucosa of the ileum than the jejunum in the 55 day old WT, $I L-1 r n^{-/}$mice and in 155185 day old WT mice (Supplementary Figure 4B and Figure 7C and 7D). Although ADAMTS1 was highly expressed in the jejunum and ileum of the $I L-1 r n^{-/}$mice, there were no significant differences between age and genotypes (Supplementary Figure 4C and Figure 7E and 7F).

Assessment of enterocyte polarity and cell-cell adherence

ZO-1 and E-cadherin were expressed from the surface of the villi down to crypts in WT mice. The level of expression of
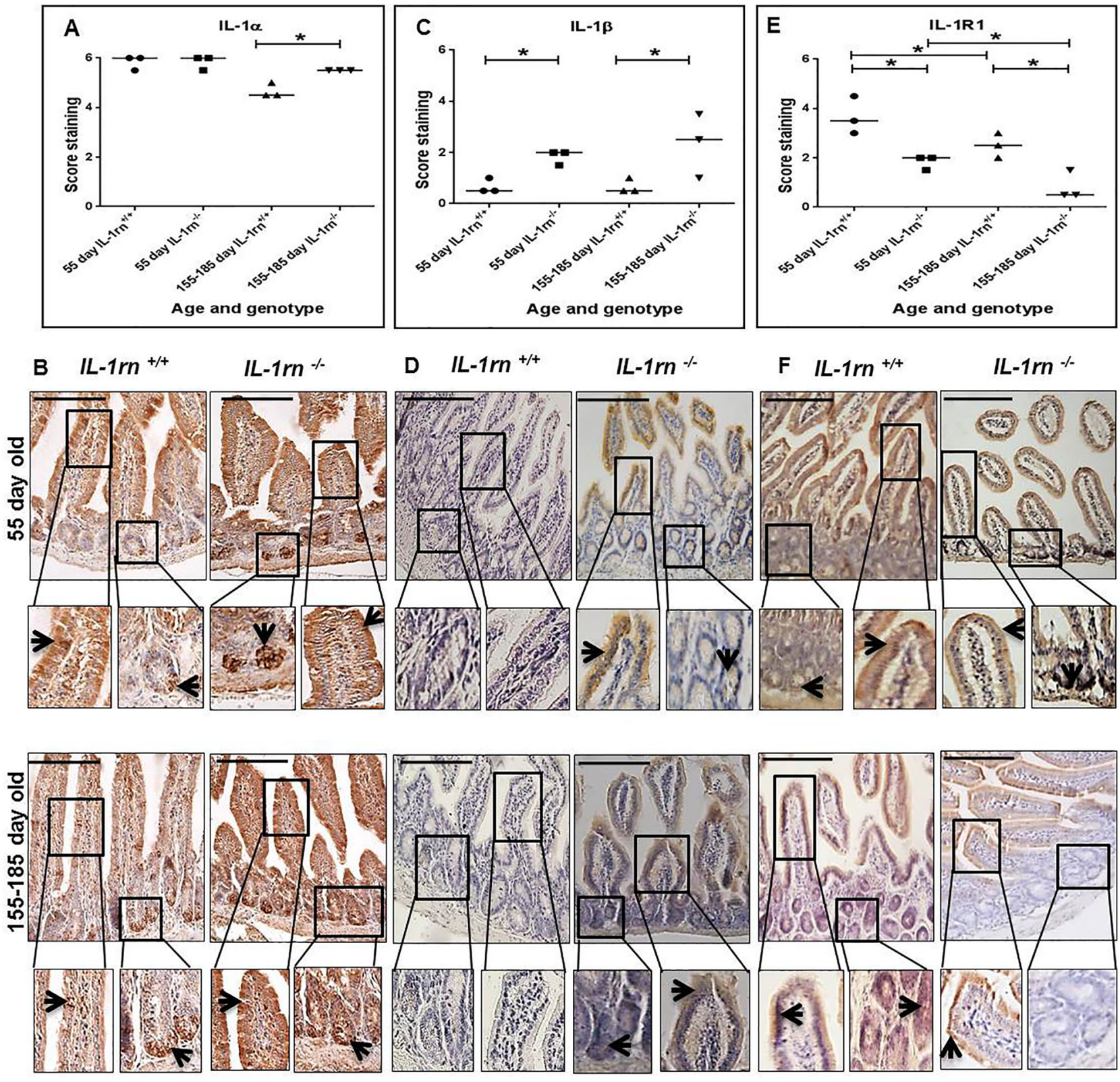

Figure 4: Immunohistochemistry staining of the expression and localization of pro-inflammatory cytokines: IL-1 $\alpha$ (A) IL$1 \beta$ (C) IL-1RI (E) show the immunopositive intensity quantification across the small intestinal architecture. (B, D) and (F) showing the immunopositive staining in the ileum of the 55 day old and 155-185 day old IL-1 $\mathrm{rn}^{-/}$mice compared with WT mice. Cell nuclei were stained with haematoxylin (blue). Black arrows indicate immunopositivity. ${ }^{*} P \leq 0.05$. Scale bar $=100 \mu \mathrm{m}$. 

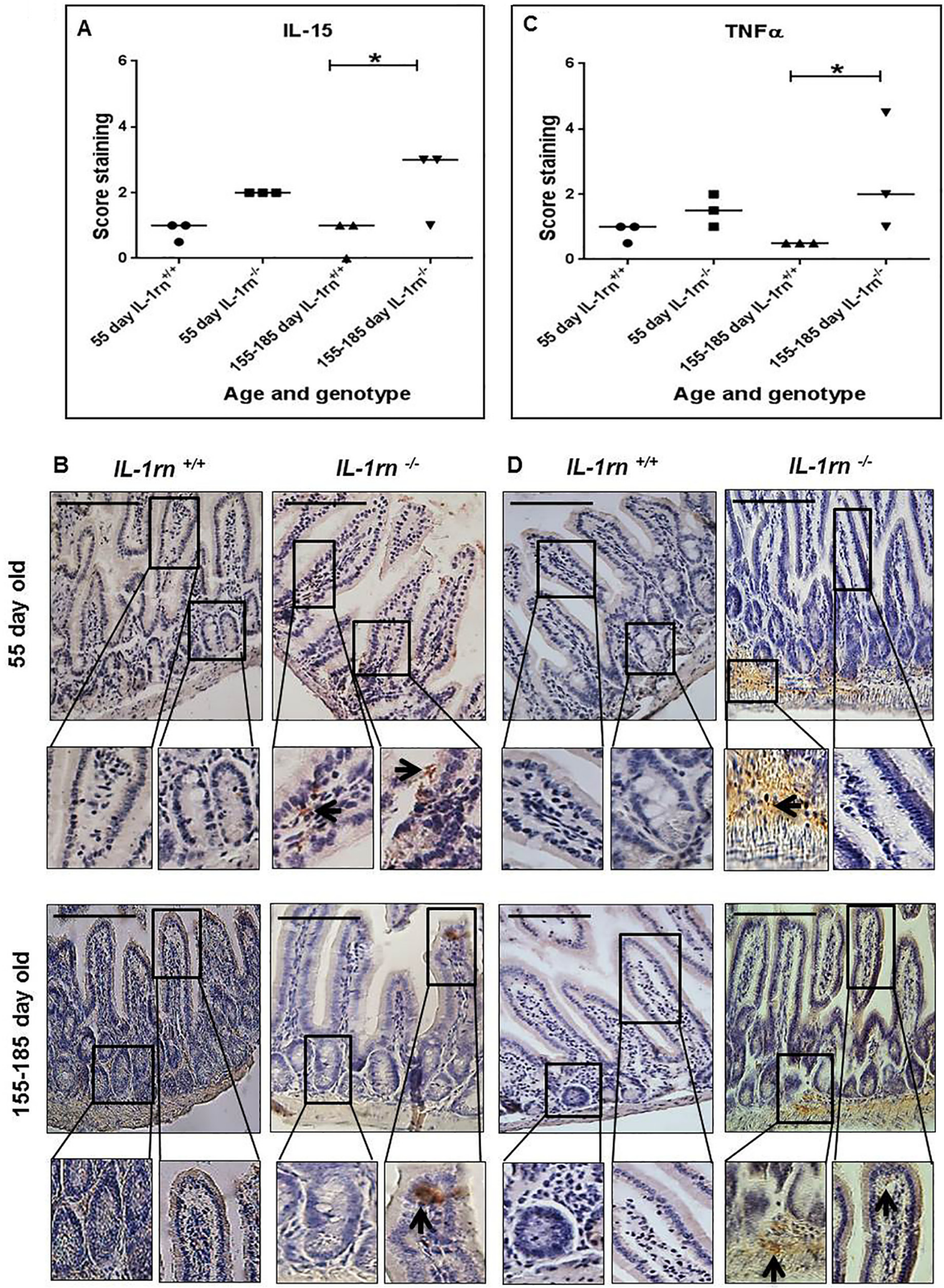

Figure 5: Immunohistochemistry staining of the expression and localization of pro-inflammatory cytokines: IL-15 (A) $\mathrm{TNF} \alpha$ (C) show the immunopositive intensity quantification across the small intestinal architecture. (B and D) showing immunopositive staining in the ileum of the 55 day old and 155-185 day old IL-1 $\mathrm{rn}^{-} /$mice compared with WT mice. Cell nuclei were stained with haematoxylin (blue). Black arrows indicate immunopositivity. ${ }^{*} P \leq 0.05$. Scale bar $=100 \mu \mathrm{m}$. 
both ZO-1 and E-cadherin was significantly decreased in both the 55 day old and 155-185 day old $I L-1 r n^{-/}$mice compared to age-matched WT controls $(\mathrm{P} \leq 0.05)$ (Supplementary Figure $5 \mathrm{~A} \& 5 \mathrm{~B}$ and Figure $8 \mathrm{~A}, 8 \mathrm{~B}, 8 \mathrm{C}, 8 \mathrm{D})$. In the jejunum, $\mathrm{ZO}-1$ expression was localized on villi tips only in the 155-185 day old $I L-1 r n^{--}$mice, which was significantly less than that seen in younger 55 day old of $I L-1 r^{--}$and WT mice (Supplementary Figure 5A). In contrast, ZO-1 was uniformly expressed at the cell surface of the entire villi in the ileum and was comparable to that seen in WT mice (Figure 8A and 8B). E-cadherin immunopositivity was lost in the jejunum and ileum of 155-185 day old of $I L-1 r n^{--}$mice compared to WT mice (Supplementary Figure 5B and Figure 8C \& 8D).
Assessment of digestive enzyme expression and localization

ALP expression was weak in all mice; however, specific ALP immunopositivity was seen on the brush border of the enterocytes and in the lamina propria cells (Supplementary Figure 6A and Figure 9A \& 9B).

Sucrase-isomaltase expression was localized to the apical epithelial surface and was highly expressed in all mice (Supplementary Figure 6B and Figure 9C \& 9D). DPP IV expression was increased in 55-day old $I L-1 r n-/-$ mice compared with WT mice $(\mathrm{P} \leq 0.05)$, this expression was localized on the enterocyte surface and in the lamina propria cells (Supplementary Figure 6C and Figure 9E \& 9F).
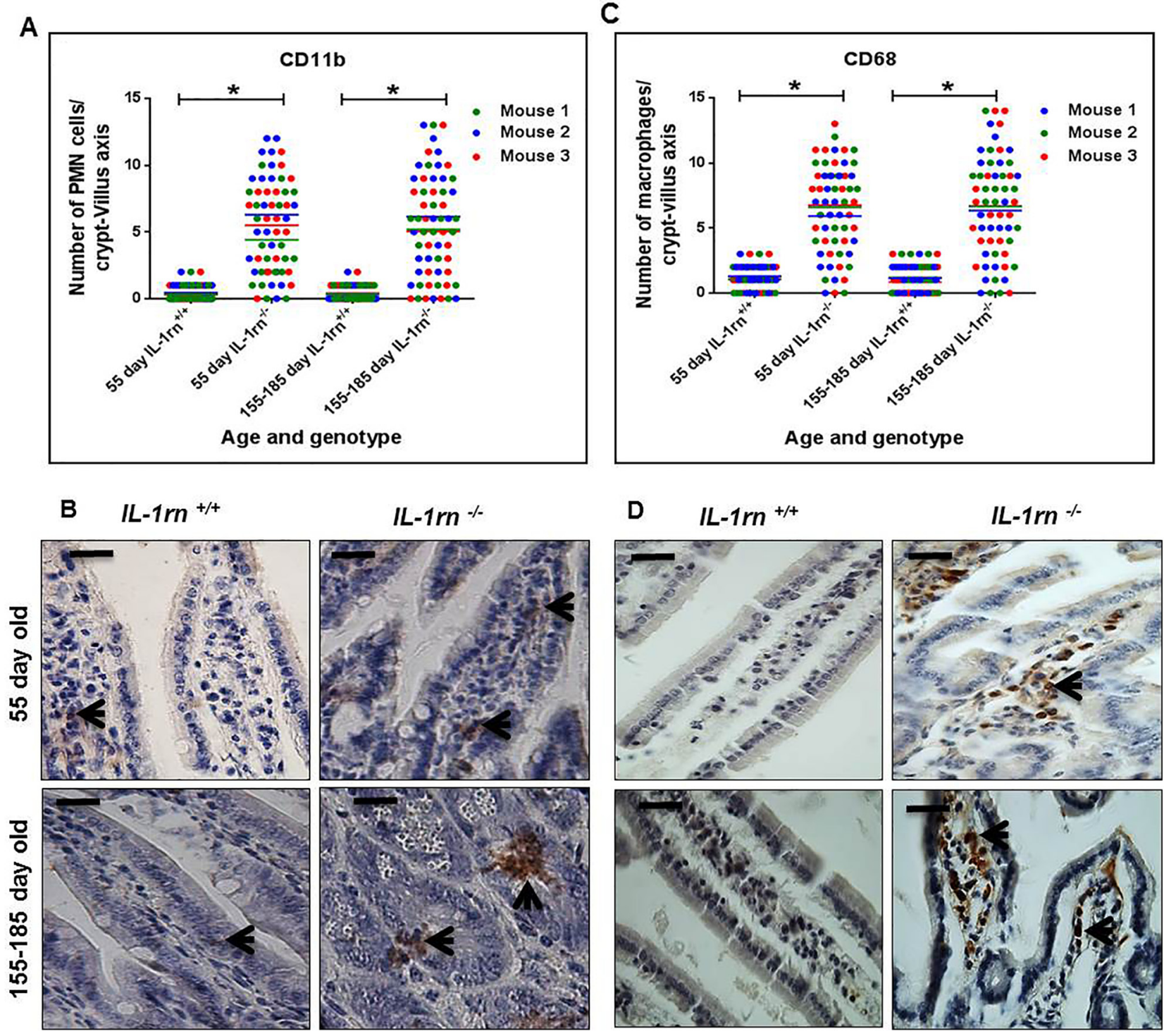

Figure 6: Immunohistochemistry staining of the infiltrated cells: Polymorphonuclear cells (PMNs) (A and B) and macrophage cells (C and D) into the lamina propria of the intact well oriented crypt-villus axis in the ileum of the 55 day old and 155185 day old IL-1 $\mathrm{rn}^{-/}$mice compared with WT mice. Cell nuclei were stained with haematoxylin (blue). Black arrows indicate immunopositivity. ${ }^{*} P \leq 0.05$. Scale bar $=25 \mu \mathrm{m}$. 


\section{DISCUSSION}

The balance between IL-1 and IL-1Ra as an endogenous inhibitor plays an essential role in stimulation and regulation of inflammation in IBD [1], however, whether IL-1 is an important causative factor in IBD or purely a result of inflammation is not currently understood. Thus, this study investigated whether changes seen during IBD could be induced spontaneously by the removal of IL-1Ra in mice that lack a functional
$I L-1 r n$ gene. In $I L-1 r n^{-/}$mice, the villi were shown to be shorter in the jejunum, while shorter and thinner in the ileum, within the ileum of older mice a $13 \%$ decrease in height and $15 \%$ decrease in width was observed. These large changes would result in a substantial decrease in digestive and absorptive area, and thus be expected to lead to defiency in nutrient uptake. This blunting of the villi is a common microscopic feature of IBD and has been observed in patients with Crohn's disease in both the jejunum and the ileum [12]. In contrast, in WT mice
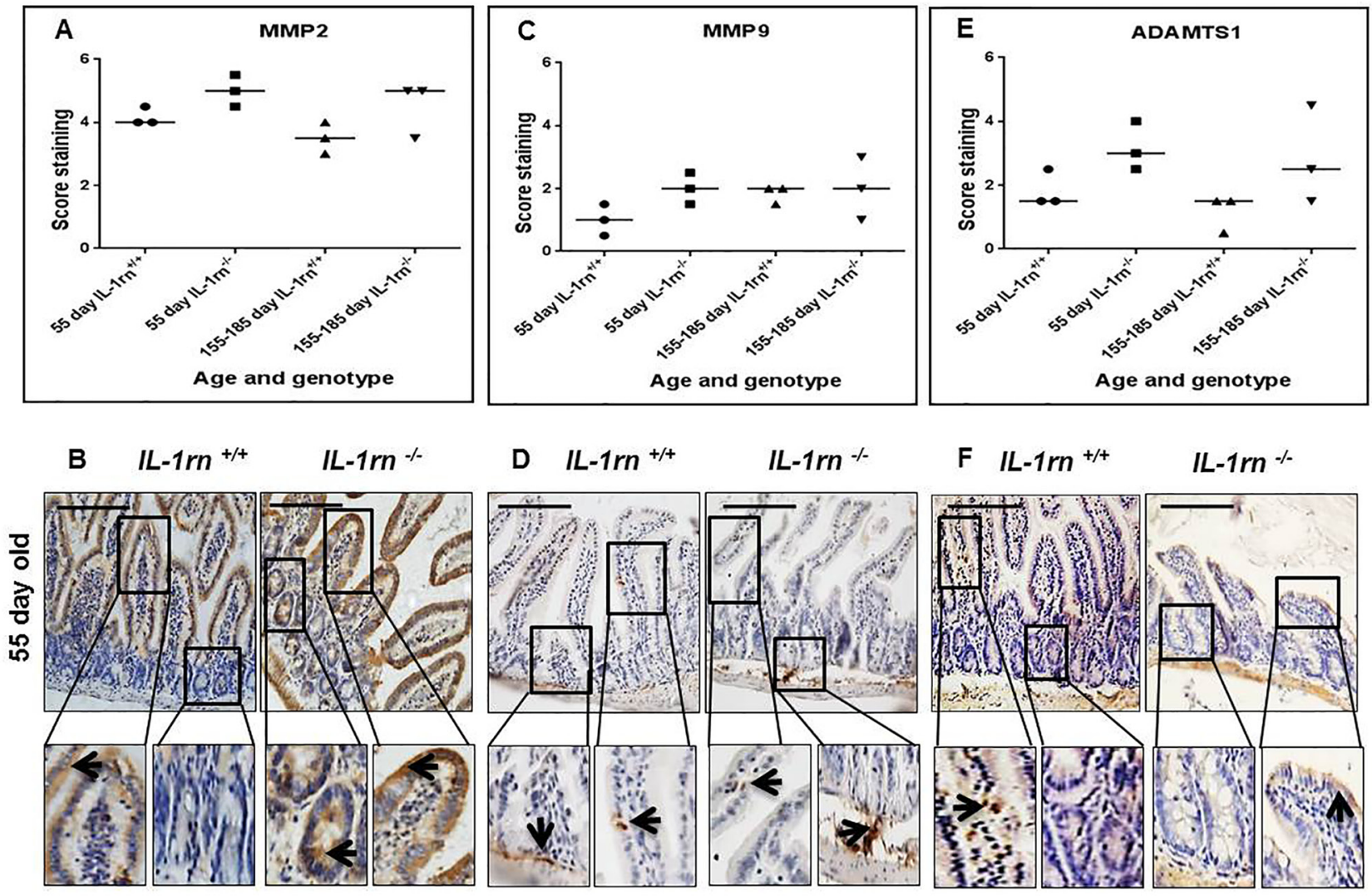

F $I L-1 r n^{+/+}$

IL-1rn $\%$
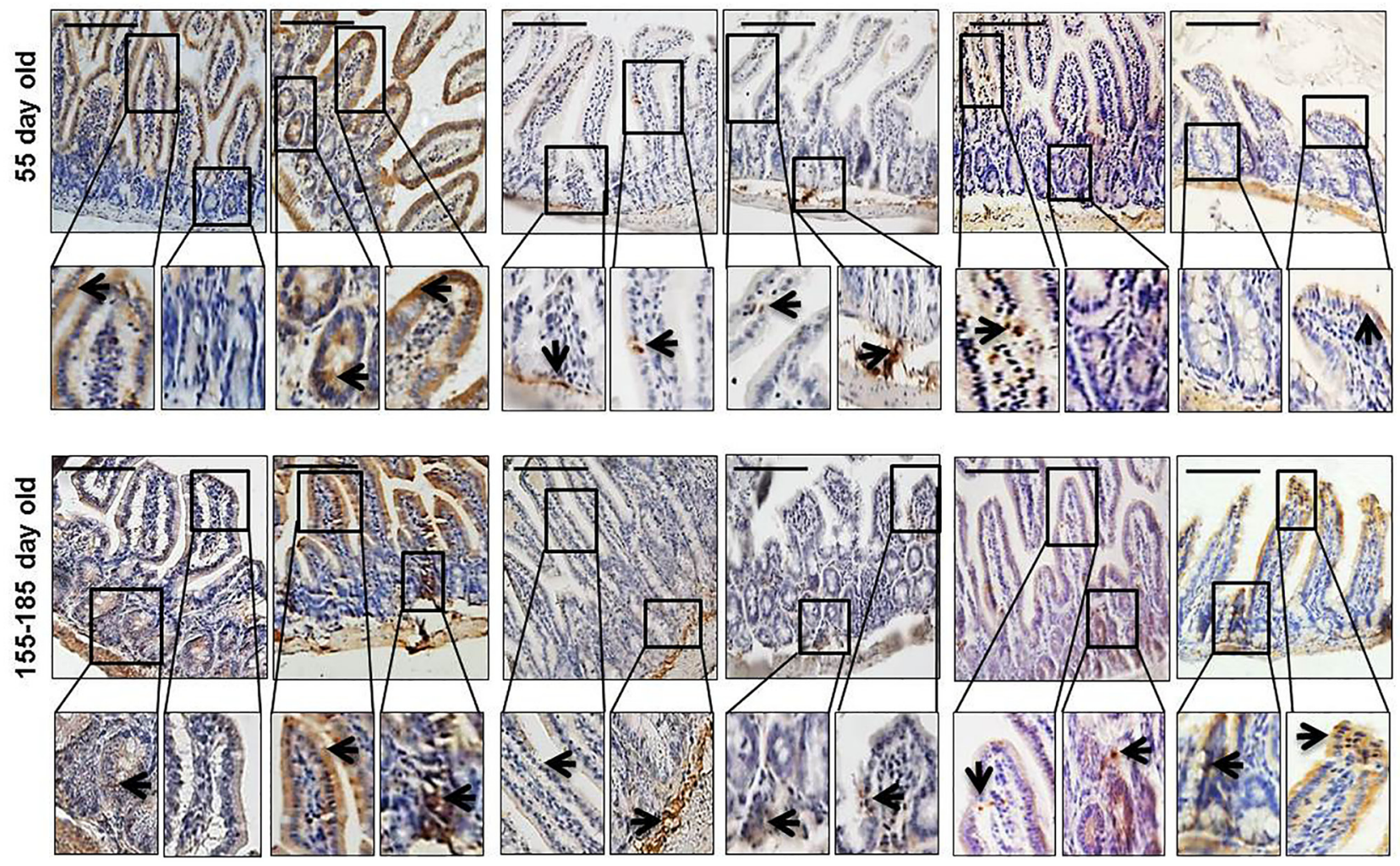

Figure 7: Immunohistochemistry staining of the expression and localization of degrading enzymes: MMP2 (A) MMP9 (C) ADAMTS1 (E) show the immunopositive intensity quantification across the small intestinal architecture. (B, D and F) showing the immunopositive staining in the ileum of the 55-day old and 155-185 day old IL-1 $\mathrm{rn}^{-/}$mice compared with WT mice. Cell nuclei were stained with haematoxylin (blue). Black arrows indicate immunopositivity. Scale bar $=100 \mu \mathrm{m}$. 

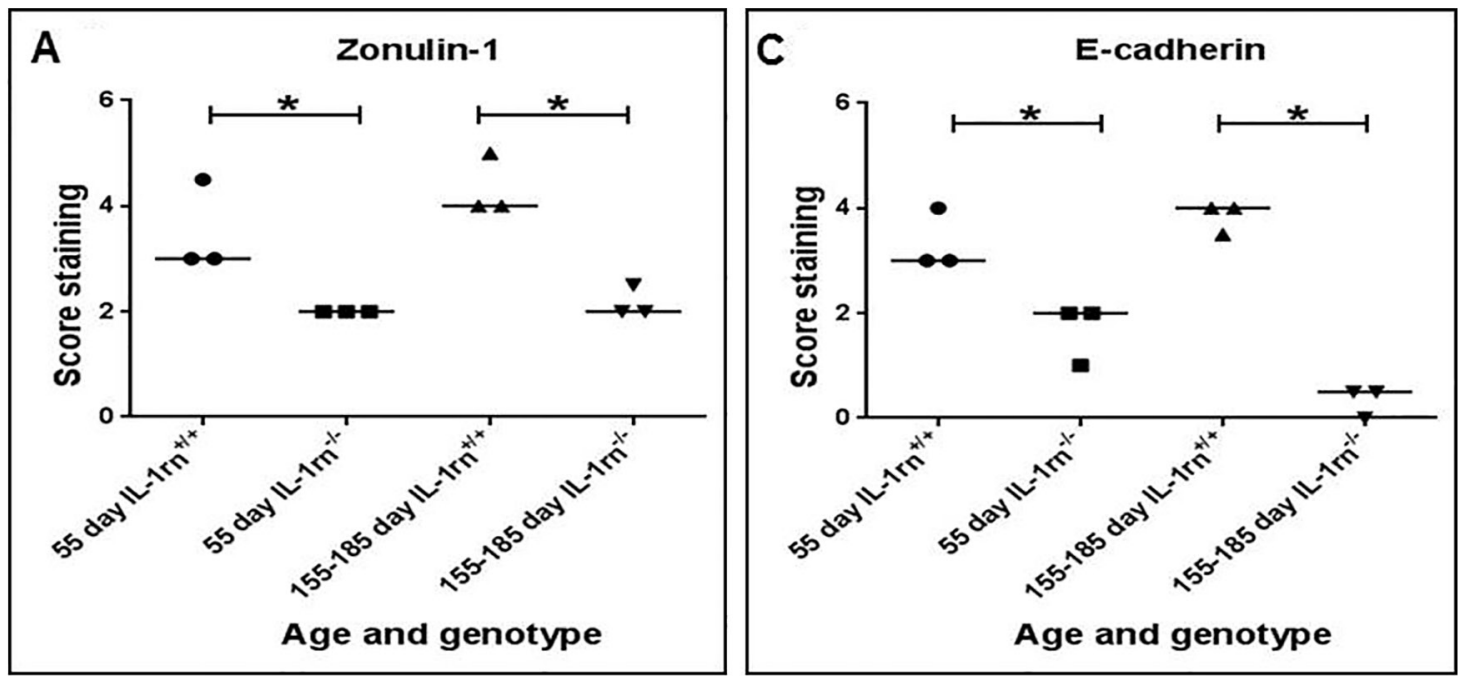

B $\quad l L-1 r n^{+/+}$
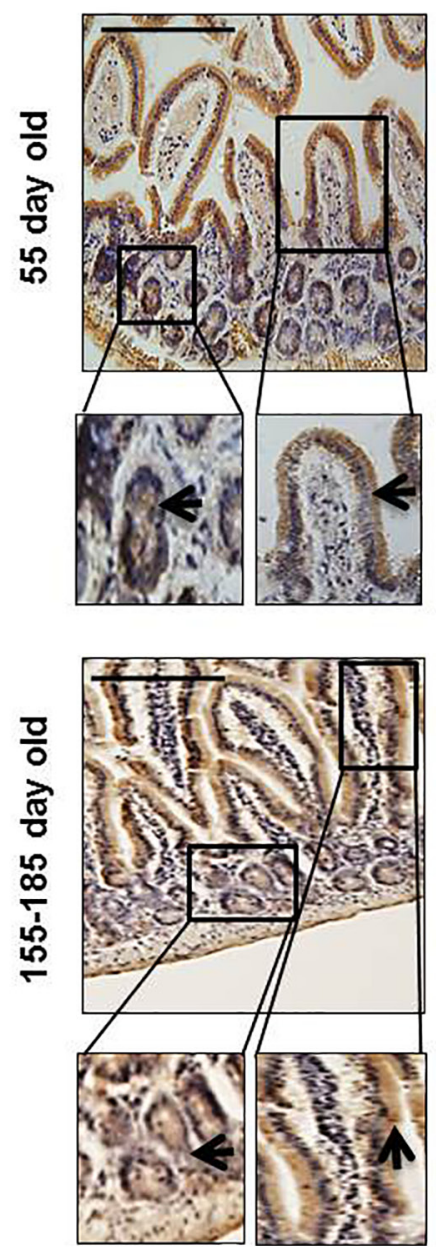

IL-1rn $\%$
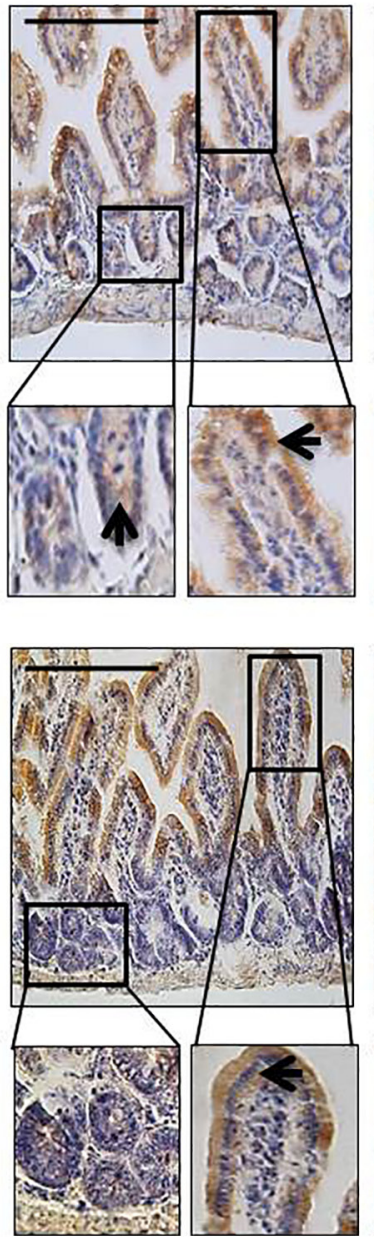

D $\quad$ LL-1rn ${ }^{+/+}$
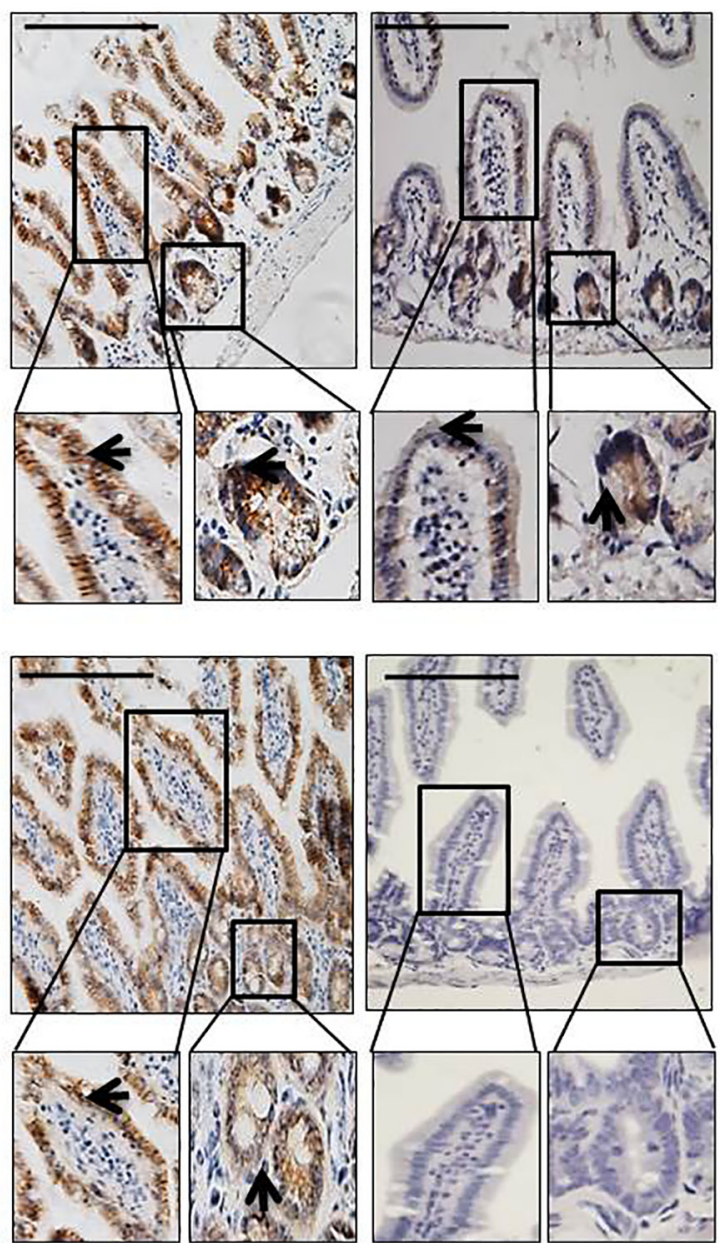

Figure 8: Immunohistochemistry staining of the expression and localization of junctional proteins: ZO-1 (A) E-cadherin (C) showing the immunopositive intensity quantification across the small intestinal architecture. (B and D) show the immunopositive staining in the ileum of the 55 day old and 155-185 day old IL-1 $\mathrm{rn}^{-/}$mice compared with WT mice. Cell nuclei were stained with haematoxylin (blue). Black arrow sindicate immunopositivity. ${ }^{*} P \leq 0.05$. Scale bar $=100 \mu \mathrm{m}$. 
the villus height and width were shown to be comparable to those of wild-type C57BL/6J mice of a similar age and region of the small intestine [13]. As seen in the WT mice, there was a decrease in height and width along a proximal-distal gradient of the small intestine. Similarly to these findings, in a wild-type C57BL/6J mice model a comparison of old and young mice, showed an increase in villi height with age, whilst the villi width was unchanged [13].
Physiologically intestinal goblet cells secrete large amounts of mucus, which coat and cover the intestinal villi. This mucus plays an important role in the maintenance of the intestinal mucosal barrier and creates a milieu in which digestion and absorption take place [14]. Here, a substantial increase in the number of goblet cells per villus in both jejunum and ileum of $I L-1 \mathrm{rn}^{-/}$mice compared with WT mice was observed which reached 22$29 \%$ more goblet cells in the ileum. This large increase
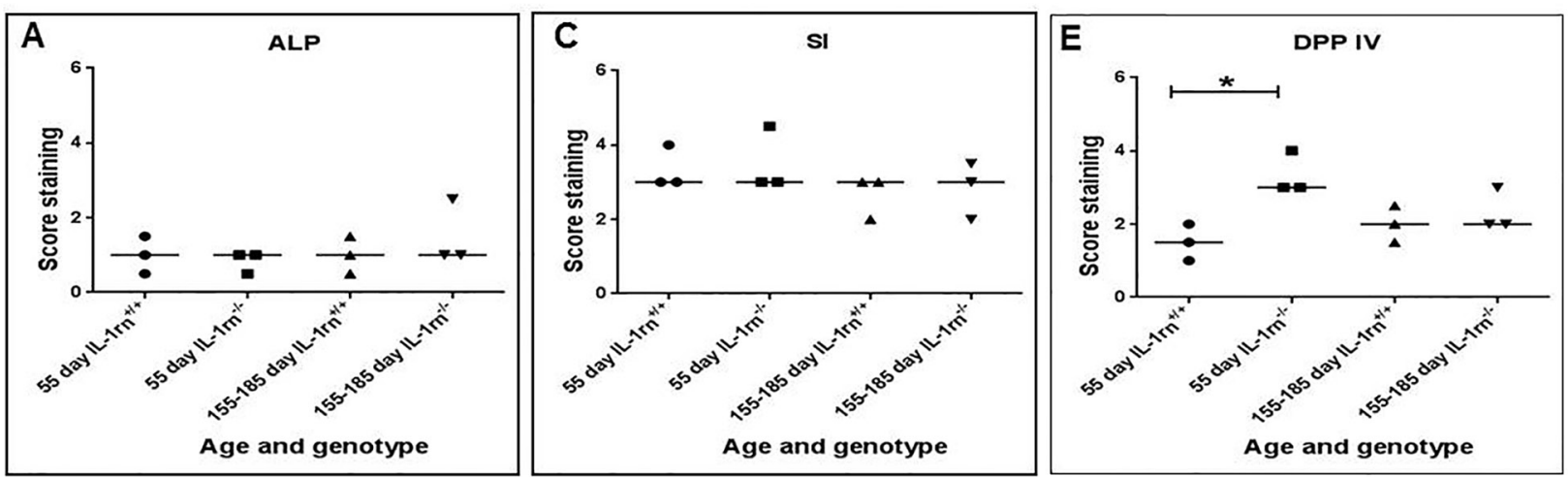

B IL-1rn ${ }^{+/+}$

IL-1rn ${ }^{-1}$

D IL-1rn ${ }^{+/+}$

IL-1 $r n^{\%}$

F $\quad I L-1 r n^{+/+}$

IL-1rn $\%$
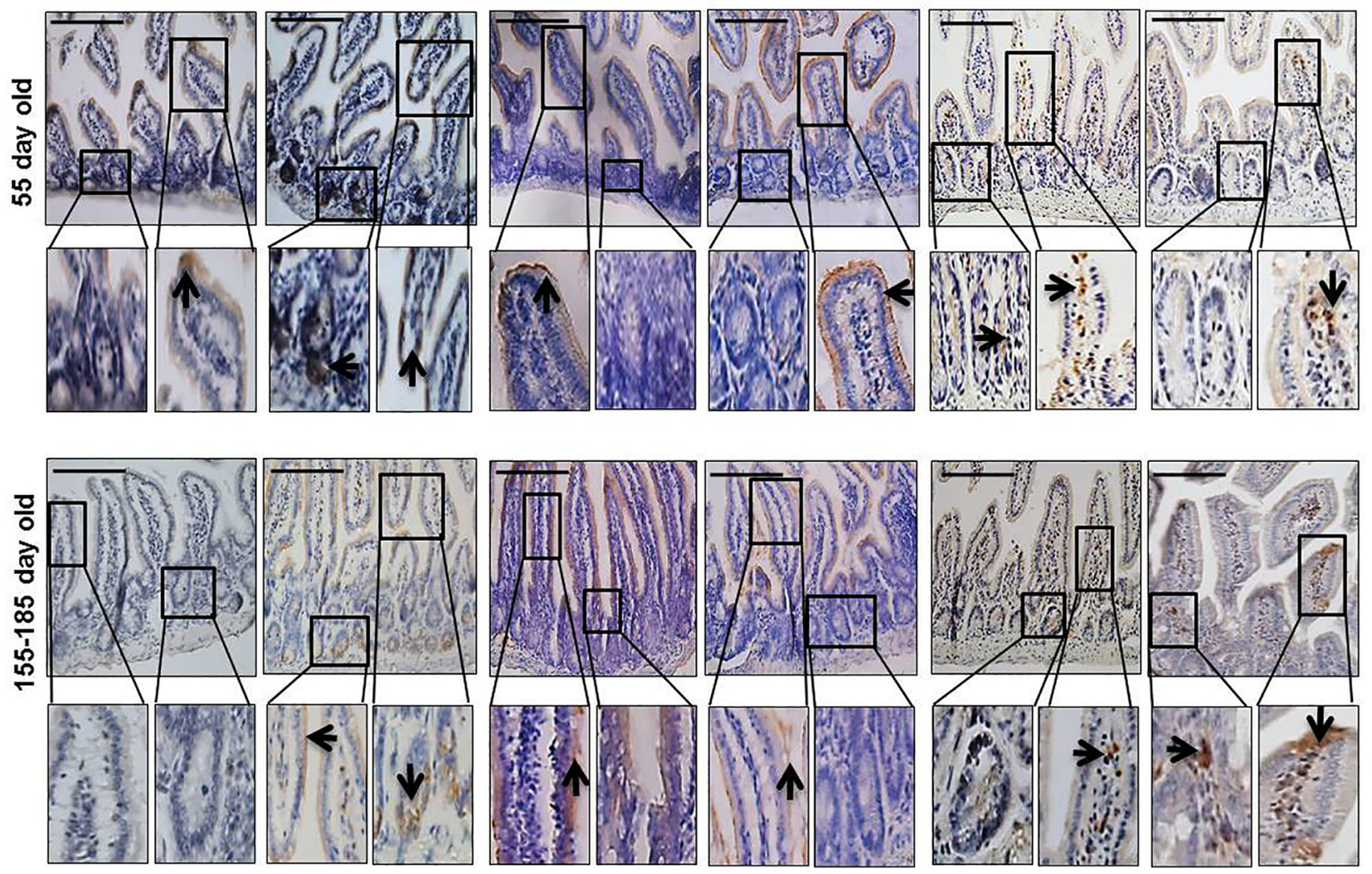

Figure 9: Immunohistochemistry staining of the expression and localization of the digestive enzymes: ALP (A) SI (C) and DPP IV (E) show the immunopositive intensity quantification across the small intestinal architecture. (B, D and F) showing the immunopositive staining in the ileum of the 55 day old and 155-185 day old IL-1 $\mathrm{rn}^{-/}$mice compared with WT mice. Cell nuclei were stained with haematoxylin (blue). Black arrows indicate immunopositivity. ${ }^{*} P \leq 0.05$. Scale bar $=100 \mu \mathrm{m}$. 
in goblet cells which accompanies the inflammatory process is believed to be caused by increased expression of the transcription factors: Hath1 (a basic helix-loop-helix (bHLH) transcription factor) and Klupper like factor 4 (KLF4), which are essential for goblet cell differentiation [15]. This inflammatory process is believed to drive the increase in goblet cell differentiation, which is observed in Crohn's disease patients [15]. However, it is important to note that this increase in goblet cells is not found in all Crohn's disease patients, or throughout the whole gastrointestinal tract [16].

Maintenance of intestinal homeostasis is regulated by epithelial barrier integrity [17]. Diffusion of the luminal materials into lamina propria promotes a local inflammatory response causing release of proinflammatory cytokines, release of MMPs, and epithelial degradation and inflammation [18]. Expression of pro-inflammatory cytokines: IL- $1 \alpha$, IL-1 $\beta$, TNF $\alpha$, and IL-15 were increased in $I L-1 r n^{-/}$mice, and these results are in agreement with those obtained from patients with Crohn's disease [19]. IL-1 $\alpha$ and IL-1 $\beta$ are also expressed in human intestinal epithelial cells [20]. IL-1 $\alpha$ is released when these human intestinal cells are damaged or destroyed, and IL-1 $\alpha$ was commonly detected in the epithelium of IBD, released from necrotic intestinal epithelial cells and plays a crucial role in intestinal inflammation by inducing human intestinal fibroblasts to produce IL-6 and IL-8 [21]. The high concentrations of IL-1 $\beta$ in the intestine of patients with Crohn's disease are mainly attributed to local mononuclear cell infiltration [22], which were also observed in this model. Increased production of IL-1 $\beta$ and TNF $\alpha$ in inflamed Crohn's disease mucosa induces the synthesis of IL-8, which is an effective neutrophil chemoattractant [23]. These findings agree with previous work, which showed increased numbers of TNF $\alpha$ positive cells in the lamina propria and submucosa of patients with Crohn's disease. Furthermore, TNF $\alpha$ produced by subepithelial macrophages has been shown to contribute to decreased epithelial integrity [24]. TNF $\alpha$ acts as an important mediator of inflammation through MAPK and NF- $\mathrm{KB}$ activation, increasing cell proliferation and altering epithelial barrier permeability [25]. The production of TNF $\alpha$ is also high in cultured mucosal mononuclear cells from Crohn's disease patients [26]. However, in contrast a previous study observed no differences in TNF $\alpha$ mRNA expression between control and IBD mucosal biopsies [27].

IL-1RI is expressed on many cell types including $\mathrm{T}$ cells, fibroblasts, and intestinal epithelial cells. Despite the increased expression of IL- $1 \beta$ in the $I L-1 r n^{-/}$mice, the expression of IL-1R1 was reduced; this could suggest a negative feedback loop decreasing expression of IL-1RI in the presence of uncontrolled IL-1 production. This agrees with a previous study, which showed IL-1 $\beta$ and TNF $\alpha$ treatment downregulated the expression of mRNA IL-1RI in rat intestinal epithelial cells (IEC-6) [28]. Similarly, IL-1 $\beta$ treatment was also shown to downregulate IL-1RI protein in retinal endothelial cells (TR-iBRB2) [29]. This is contrary to previous study, in which an increase in IL$1 \beta$ induced chronic intestinal inflammation in mice and an increase in IL-17A-secreting innate lymphoid cells which express high levels of IL-1R1 [30]. These differences may be a result of the different levels of inflammation seen in these models. Here, increased expression of IL-15 was seen in $I L-1 \mathrm{rn}^{-/}$mice, this is in agreement with Liu et al (2000), who showed increased expression of IL-15 by macrophages in the inflamed ileum of patients with Crohn's disease and that IL-15 increased local T cell activation and induced proinflammatory cytokine production by $\mathrm{T}$ cells and macrophages. The presence of polymorphonuclear cells and mononuclear cells play an important role in the augmentation of inflammation and tissue damage in IBD [31]. Increased infiltration of these CD11b and CD68 positive cells into the lamina propria were observed in $I L-1 r n^{-/}$mice compared with WT mice. These findings are in agreement with previous findings which showed increased numbers of these cells in the inflamed mucosa of IBD patients [32]. Infiltration of immune cells such as macrophages and lymphocytes in the lamina propria is an important aspect of IBD, especially Crohn's disease, even in the lack of noticeable morphological, clinical, and endoscopic indication of inflammation. This is thought to be due to an increased demand of macrophages within the inflamed intestine [33]. Functional assessment of this increased inflammatory response such as calprotectin measurement in stool samples would have been a useful assessment, however unfortunately these samples were not available in this study.

MMPs and ADAMTS1 expression were not significantly altered in $I L-1 r n^{-/}$mice. MMPs have been demonstrated to be induced in several pathological conditions of IBD and play a key role in regulating the pathophysiology of IBD [34]. The main action of MMPs is to degrade extracellular matrix proteins. Active MMP2 and MMP9 play an important role in cell migration and cytokine stimulation. Indeed neutrophil infiltration has been shown to be induced by upregulation of MMP9 in murine inflamed intestine [35]. Furthermore, stromal cells play an important role in intestinal inflammation and the pathogenesis of IBD. These cells secrete MMP2 and MMP9 [36]; and MMP9 is produced by human colonic epithelium during IBD [37]. In addition, infiltrating macrophages and neutrophils are the main source of MMP9 in human IBD [38]. Overexpression of MMP9 has been shown to cause a reduction in the differentiation of progenitor cells to goblet cells and consequently decreased MUC2 expression, which leads to decreases in the protective mucin barrier in colonic epithelium [35].

The maintenance of epithelial barrier function and control of paracellular permeability are regulated by tight junction proteins [39]. Epithelial disruption and decrease in tight junctions that lead to increased intestinal permeability are the common features of Crohn's disease [40]. Decreased expression of ZO-1 and loss of E-cadherin 
Table 1: Target antibodies used for IHC, their optimal concentration and antigen retrieval methods

\begin{tabular}{lccccc}
\hline Antibody & Clonality & Dilution & $\begin{array}{c}\text { Antigen } \\
\text { retrieval }\end{array}$ & Supplier & Catalogue No. \\
\hline IL-1 $\alpha$ & Rabbit polyclonal & $1: 100$ & Heat & Abcam & ab7632 \\
IL-1 $\beta$ & Rabbit polyclonal & $1: 100$ & Heat & Abcam & ab9722 \\
IL-1R1 & Rabbit polyclonal & $1: 100$ & Enzyme & Abcam & ab106278 \\
IL-15 & Rabbit polyclonal & $1: 50$ & Enzyme & Abcam & ab7213 \\
TNF $\alpha$ & Rabbit polyclonal & $1: 50$ & Enzyme & Abcam & ab6671 \\
CD11b & Goat polyclonal & $1: 600$ & None & Abcam & ab62817 \\
CD68 & Mouse monoclonal & $1: 200$ & Enzyme & Abcam & ab955 \\
MMP2 & Rabbit polyclonal & $1: 800$ & Enzyme & Abcam & ab37150 \\
MMP9 & Rabbit polyclonal & $1: 25$ & Heat & Abcam & ab38898 \\
ADAMTS1 & Rabbit polyclonal & $1: 200$ & Enzyme & Abcam & ab39194 \\
ZO-1 & Rabbit polyclonal & $1: 50$ & Enzyme & Abcam & ab217334 \\
E-cadherin & Mouse monoclonal & $1: 200$ & Heat & Abcam & ab76055 \\
ALP & Rabbit monoclonal & $1: 200$ & Heat & Abcam & ab108337 \\
SI & Mouse monoclonal & $1: 50$ & Heat & Santa Cruz & sc-393470 \\
DPP I & Mouse monoclonal & $1: 50$ & Enzyme & Abcam & ab119346 \\
\hline
\end{tabular}

expression were observed in $I L-1 \mathrm{rn}^{-/}$mice, suggesting a dysfunctional and leaky epithelial barrier, and separation of the mucosa and lamina propria. Inflammatory cytokines are known to affect epithelial junctional complexes, causing barrier dysfunction and increased epithelial permeability [39]. A previous study showed that a tight junction disorder has been found in the epithelial cells of the terminal ileum from patients with Crohn's disease [41]. In addition, it has been shown that IL-1 $\beta$ and TNF $\alpha$ induced defects in intestinal epithelial tight junctions resulting in increased intestinal permeability [42].

ALP plays an essential role in maintaining small intestinal homeostasis and has been shown to prevent the activation of NF-kB, thus inhibiting release of proinflammatory cytokines. Decreased activity of ALP could increase intestinal inflammation [43], and intestinal epithelial dysfunction in IBD patients has been attributed to lower intestinal expression and activity of ALP [44]. Surprisingly, the expression of digestive enzymes were not altered in $I L-1 r^{-/-}$mice compared with WT mice. This demonstrated the resilience of the intestine to maintain function even during severe inflammation. SI expression was unchanged, which is contrary to decreased gene expression of SI in villus enterocytes seen in the ileum of patients with Crohn's disease [45]. DPP IV expression, however, was significantly increased in the young $I L$ $1 r n^{-\alpha}$ mice, but not the older $I L-1 r n^{-/}$mice compared to WT mice. A similar loss of DPPIV activity has been seen in the serum of patients with IBD [46].

\section{MATERIALS AND METHODS}

\section{$I L-1 r n^{-/}$BALB/c mice}

$I L-1 r n^{\text {tmINick }}$ deficient mice $\left(I L-1 r n^{-/}\right)$have been described previously [47]. All mice were housed behind positive pressure barriers and were reared under UK Home Office licenses. All materials were supplied sterile and certified pathogen free. This work was approved by the University of Sheffield ethical review panel. Formalinfixed mice were a kind gift from Dr. Martin Nicklin, University of Sheffield. To ensure that experimental procedures aligned with the 3 Rs principle, initial work was completed on $\mathrm{n}=4$ and statistical analysis performed, as statistically significant differences were seen in $n=4$ it was not deemed ethically appropriate nor necessary to increase the number of animals utilised.

\section{Tissue preparation and histological assessment}

The entire jejunum and ileum portions of small intestine were dissected from BALB/c $I L-1 r n^{-1}$ knockout mice aged 50-55 days $(n=4)$ and $155-185$ day old $(n=4)$, together with age-matched BALB/c wild-type (WT) controls ( $\mathrm{n}=4$ at each age). Following dissection, tissues were rinsed in PBS and fixed in $10 \% \mathrm{v} / \mathrm{v}$ formalin for 24 $\mathrm{h}$ and then transferred to $70 \% \mathrm{v} / \mathrm{v}$ ethanol. Tissues were processed and embedded in paraffin wax. Five-micron sections were cut and mounted onto positively charged 
slides (Leica Microsystem Milton Keynes, UK). Sections were deparaffinised in Sub-X and rehydrated in industrial methylated spirits (IMS) prior to rehydration in distilled water. Sections were then stained with either: Haematoxylin and Eosin; Mayer's Haematoxylin (Leica Microsystem, Milton Keynes, UK) for $2 \mathrm{~min}$ rinsed in water for $5 \mathrm{~min}$ and immersed in Eosin (Leica Microsystem, Milton Keynes, UK) for $1 \mathrm{~min}$; or Alcian Blue/Periodic acid Schiff's (PAS): 1\% w/v Alcian Blue (PH 2.5) (Sigma-Aldrich, Poole, UK) in $3 \%(\mathrm{v} / \mathrm{v})$ acetic acid (Sigma-Aldrich, Poole, UK) for $30 \mathrm{~min}$ and immersed in $0.5 \%(\mathrm{w} / \mathrm{v})$ Periodic acid for 10 min and rinsed three times in deionised water. Slides were then immersed in Schiff reagent (Merck KGaA, Germany) for $10 \mathrm{~min}$, and then rinsed three times with deionised water. Following staining, sections were dehydrated in IMS, cleared with Sub-X and mounted in Pertex (Leica Microsystem, Milton Keynes, UK). The slides were examined with an Olympus BX 51 microscope and images captured by the digital camera and Capture Pro OEM V8.0 software (Media Cybernetics, Buckinghamshire, UK).

The tissue morphology was assessed using the Capture Pro OEM V8.0 software measurement tools as follows:

\section{Crypt-villus height and villus width}

Twenty well oriented crypt-villus axes height and villus width at half-axis height in longitudinal tissue sections were measured in the jejunum and ileum of all mice, from each age range and genotype.

\section{Goblet cells per crypt-villus axis}

The numbers of goblet cells within twenty well oriented crypt-villus axes were counted in the jejunum and ileum of all mice from each age range and genotype.

\section{Immunohistochemical assessment}

\section{Pro-inflammatory cytokine expression and immune cell infiltration}

The expression of pro-inflammatory cytokines IL- $1 \alpha$, IL-1 $\beta$, and their receptor: IL-1RI; IL-15, and $\mathrm{TNF} \alpha$ were investigated by immunohistochemistry. In addition, the number of immune cells which infiltrated into lamina propria of crypt-villus axis was determined using immunohistochemistry of polymorphonuclear cell marker: CD11b and macrophage marker CD68, in the jejunum and ileum of three randomly selected mice, from each age range and genotype.

\section{Matrix-degrading enzyme expression}

The expression of matrix-degrading enzymes: MMP2, MMP9, and ADAMTS1 were assessed in the jejunum and ileum of three randomly selected mice, from each age range and genotype using immunohistochemistry.

\section{Polarity of enterocytes and digestive enzyme expression}

The expression of tight junction proteins Zonulin 1 (ZO-1) and adherent junction protein E-cadherin, were assessed alongside digestive enzymes: alkaline phosphatase (ALP), sucrase-isomaltase (SI), and dipeptidyl peptidase IV (DPP IV) in the jejunum and ileum of three randomly selected mice, from each age range and genotype.

Immunohistochemistry was performed as described previously [48]. Briefly, $5 \mu \mathrm{m}$ sections were de-waxed, rehydrated, and endogenous peroxidase blocked using hydrogen peroxide (Sigma-Aldrich, Poole UK). After washing in Tris-buffered saline (TBS) (20mM Tris, $150 \mathrm{mM}$ sodium chloride, $\mathrm{pH} 7.5$ ), tissue sections were subjected to antigen retrieval sections were subjected to an appropriate antigen retrieval method, specific to the antibodies investigated (Table 1). Following this sections were washed in TBS. Then nonspecific binding sites were blocked at room temperature for 90 min with $25 \%(\mathrm{w} / \mathrm{v})$ serum (Abcam, Cambridge, UK) in 1\% (w/v) bovine serum albumin in TBS. Sections were incubated overnight at $4{ }^{\circ} \mathrm{C}$ with appropriate primary antibody (Table 1).

For each immunohistochemistry method, a negative control was performed, replacing the primary antibody with either rabbit or mouse IgG (Abcam, Cambridge, UK) as appropriate, at a concentration equal to that of the primary antibody. Sections were washed in TBS and then incubated in 1:500 dilution of an appropriate biotinylated secondary antibody for $30 \mathrm{~min}$ at room temperature. Binding of the secondary antibody was visualised after exposure to horseradish peroxidase (HRP) streptavidin-biotin complex (Vector Laboratories, Peterborough, UK) for $30 \mathrm{~min}$. Sections were washed in TBS, and treated with $0.08 \%(\mathrm{v} / \mathrm{v})$

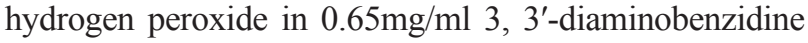
tetrahydrochloride (Sigma-Aldrich, Poole, UK) in TBS for $20 \mathrm{~min}$. Sections were counterstained with Mayer's haematoxylin, dehydrated, cleared and mounted in Pertex. Immunohistochemical staining were examined with an Olympus BX51 microscope and images captured by digital camera and Capture Pro OEM v8.0 software (Media Cybernetics, Buckinghamshire, UK). Immunopositive intensity across the small intestine architecture was independently semi-quantified by two assessors (CLM and NJM), blinded to animal genotype and age. A scale of 0 to 6 was utilised where 0 was no immunopositivity and 6 signifies maximum immunopositivity. The number of immunopositive (CD11b and CD68) immune cells were counted within twenty well oriented crypt-villus axes of each of three randomly selected mice, from each age range and genotype.

\section{Statistical analysis}

Data was plotted using GraphPad Prism V6.0. Crypt-villus axes height and villus width were assessed for normality using Stats Direct program and found to 
be non-parametric and therefore statistical comparisons were performed by Kruskal-Wallis with a pairwise comparison (Conover-Inman) between ages and genotypes. Statistical significance was set at $\mathrm{P} \leq 0.05$, for statistical analysis the mean villi height, width and goblet cells per villi per mouse were utilised for statistical analysis. All replicates are shown with the median values for each mouse to demonstrate clearly the spread of replicates.

\section{CONCLUSIONS}

IL-1Ra deficient mice ( $\left.I L-1 r n^{-/}\right)$induced spontaneous intestinal inflammation which provides an effective approach to display features associated with IBD. Old $I L-1 r n^{-/}$mice demonstrated a higher inflammatory response than young $I L-1 r n^{-/}$mice. This model delivers evidence for a role of the imbalance between IL-1 and IL-1Ra in the pathogenesis of IBD and could provide a useful model for testing new therapies.

\section{Abbreviations}

IBD, Inflammatory bowel disease; IL1, Interleukin 1; IL-1Ra, Interleukin 1 receptor antagonist; IL-1R1, Interleukin 1 receptor 1; WT, Wild type; MMPs, Matrix-degrading enzymes; ADAMTS1, A disintegrin and metalloproteinase with thrombospondin motifs; CD, Crohn's disease; UC, Ulcerative colitis; PMNs, Polymorphonuclear cells; AB, Alcian blue; PAS, Periodic acid schiff; TNFa, Tumor necrosis factor; ZO-1, Zonulin 1; ALP, Alkaline phosphatase; SI, Sucrase-isomaltase; DPP IV, Dipeptidyl peptidase 4 .

\section{Author contributions}

RHD performed the laboratory work, data analysis, and statistical analysis, contributed to study design and drafted the manuscript. NJM, and CLM performed analysis of IHC data. NJM, CS, and CLM conceived the study, participated in its design and analysis and critically revised the manuscript. All authors read and approved the final manuscript.

\section{ACKNOWLEDGMENTS}

The Authors would like to thank Dr. Martin Nicklin, University of Sheffield for providing formalin-fixed $I L$ $1 r n^{\text {tmlNick }}$ deficient mice $\left(I L-1 r n^{-/}\right)$.

\section{CONFLICTS OF INTEREST}

The authors declare no conflicts of interest.

\section{FUNDING}

We would like to offer kind thanks to the ministry of higher education and scientific research of Iraq for $\mathrm{PhD}$ scholarship.

\section{REFERENCES}

1. Ludwiczek O, Vannier E, Borggraefe I, Kaser A, Siegmund B, Dinarello CA, Tilg H. Imbalance between interleukin-1 agonists and antagonists: relationship to severity of inflammatory bowel disease. Clin Exp Immunol. 2004; 138:323-29. https://doi.org/10.1111/j.1365-2249.2004.02599.x. [PubMed]

2. Casini-Raggi V, Kam L, Chong YJ, Fiocchi C, Pizarro TT, Cominelli F. Mucosal imbalance of IL-1 and IL-1 receptor antagonist in inflammatory bowel disease. A novel mechanism of chronic intestinal inflammation. J Immunol. 1995; 154:2434-40. [PubMed]

3. Al-Sadi R, Ye D, Dokladny K, Ma TY. Mechanism of IL-1beta-induced increase in intestinal epithelial tight junction permeability. J Immunol. 2008; 180:5653-61. https://doi.org/10.4049/jimmunol.180.8.5653. [PubMed]

4. Ferretti M, Casini-Raggi V, Pizarro TT, Eisenberg SP, Nast CC, Cominelli F. Neutralization of endogenous IL-1 receptor antagonist exacerbates and prolongs inflammation in rabbit immune colitis. J Clin Invest. 1994; 94:449-53. https://doi.org/10.1172/JCI117345. [PubMed]

5. McCall RD, Haskill S, Zimmermann EM, Lund PK, Thompson RC, Sartor RB. Tissue interleukin 1 and interleukin-1 receptor antagonist expression in enterocolitis in resistant and susceptible rats. Gastroenterology. 1994; 106:960-72. https://doi.org/10.1016/0016-5085(94)90755-2. [PubMed]

6. Cominelli F, Nast CC, Clark BD, Schindler R, Lierena $\mathrm{R}$, Eysselein VE, Thompson RC, Dinarello CA. Interleukin 1 (IL-1) gene expression, synthesis, and effect of specific IL-1 receptor blockade in rabbit immune complex colitis. J Clin Invest. 1990; 86:972-80. https://doi.org/10.1172/JCI114799. [PubMed]

7. Kiesler P, Fuss IJ, Strober W. Experimental models of inflammatory bowel diseases. Cell Mol Gastroenterol Hepatol. 2015; 1:154-70. https://doi.org/10.1016/j.jcmgh.2015.01.006. [PubMed]

8. Olson TS, Reuter BK, Scott KG, Morris MA, Wang XM, Hancock LN, Burcin TL, Cohn SM, Ernst PB, Cominelli F, Meddings JB, Ley K, Pizarro TT. The primary defect in experimental ileitis originates from a nonhematopoietic source. J Exp Med. 2006; 203:541-52. https://doi.org/10.1084/jem.20050407. [PubMed]

9. Kosiewicz MM, Nast CC, Krishnan A, Rivera-Nieves J, Moskaluk CA, Matsumoto S, Kozaiwa K, Cominelli F. Th1-type responses mediate spontaneous ileitis in a novel 
murine model of Crohn's disease. J Clin Invest. 2001; 107:695-702. https://doi.org/10.1172/JCI10956. [PubMed]

10. Arend WP. The balance between IL-1 and IL-1Ra in disease. Cytokine Growth Factor Rev. 2002; 13:323-40. https://doi.org/10.1016/S1359-6101(02)00020-5. [PubMed]

11. Hirsch E, Irikura VM, Paul SM, Hirsh D. Functions of interleukin 1 receptor antagonist in gene knockout and overproducing mice. Proc Natl Acad Sci U S A. 1996; 93:1100813. https://doi.org/10.1073/pnas.93.20.11008. [PubMed]

12. Rutgeerts $P$, Geboes $K$, Vantrappen G, Kerremans R, Coenegrachts JL, Coremans G. Natural history of recurrent Crohn's disease at the ileocolonic anastomosis after curative surgery. Gut. 1984; 25:665-72. https://doi.org/10.1136/gut.25.6.665. [PubMed]

13. Gulbinowicz M, Berdel B, Wójcik S, Dziewiatkowski J, Oikarinen S, Mutanen M, Kosma VM, Mykkänen H, Moryś J. Morphometric analysis of the small intestine in wild type mice C57BL/6L -- a developmental study. Folia Morphol (Warsz). 2004; 63:423-30. [PubMed]

14. Atuma C, Strugala V, Allen A, Holm L. The adherent gastrointestinal mucus gel layer: thickness and physical state in vivo. Am J Physiol Gastrointest Liver Physiol. 2001; 280:G922-29. https://doi.org/10.1152/ajpgi.2001.280.5.G922. [PubMed]

15. Gersemann $M$, Becker $S$, Kübler I, Koslowski $M$, Wang G, Herrlinger KR, Griger J, Fritz P, Fellermann K, Schwab M, Wehkamp J, Stange EF. Differences in goblet cell differentiation between Crohn's disease and ulcerative colitis. Differentiation. 2009; 77:84-94. https://doi.org/10.1016/j.diff.2008.09.008. [PubMed]

16. Dorofeyev AE, Vasilenko IV, Rassokhina OA, Kondratiuk RB. Mucosal barrier in ulcerative colitis and Crohn's disease. Gastroenterol Res Pract. 2013; 2013:431231. https://doi.org/10.1155/2013/431231. [PubMed]

17. Noti M, Corazza N, Mueller C, Berger B, Brunner T. TNF suppresses acute intestinal inflammation by inducing local glucocorticoid synthesis. J Exp Med. 2010; 207:1057-66. https://doi.org/10.1084/jem.20090849. [PubMed]

18. O’Sullivan S, Gilmer JF, Medina C. Matrix metalloproteinases in inflammatory bowel disease: an update. Mediators Inflamm. 2015; 2015:964131. https://doi.org/10.1155/2015/964131. [PubMed]

19. Geboes K. Histopathology of Crohn's disease and ulcerative colitis. Inflamm Bowel Dis. 2003; 4:255-76. https://doi.org/10.1093/gastro/gou031. [PubMed]

20. Garlanda C, Dinarello CA, Mantovani A. The interleukin-1 family: back to the future. Immunity. 2013; 39:1003-18. https://doi.org/10.1016/j.immuni.2013.11.010. [PubMed]

21. Scarpa M, Kessler S, Sadler T, West G, Homer C, McDonald C, de la Motte C, Fiocchi C, Stylianou E. The epithelial danger signal IL- $1 \alpha$ is a potent activator of fibroblasts and reactivator of intestinal inflammation. Am J Pathol. 2015; 185:1624-37. https://doi.org/10.1016/j.ajpath.2015.02.018. [PubMed]
22. Mahida YR, Wu K, Jewell DP. Enhanced production of interleukin 1-beta by mononuclear cells isolated from mucosa with active ulcerative colitis of Crohn's disease. Gut. 1989; 30:835-38. https://doi.org/10.1136/gut.30.6.835. [PubMed]

23. Andus T, Targan SR, Deem R, Toyoda H. Measurement of tumor necrosis factor alpha mRNA in small numbers of cells by quantitative polymerase chain reaction. Reg Immunol. 1993; 5:11-17. [PubMed]

24. Murch SH, Braegger CP, Walker-Smith JA, MacDonald TT. Location of tumour necrosis factor alpha by immunohistochemistry in chronic inflammatory bowel disease. Gut. 1993; 34:1705-09. https://doi.org/10.1136/gut.34.12.1705. [PubMed]

25. Guan Q, Zhang J. Recent Advances: The Imbalance of Cytokines in the Pathogenesis of Inflammatory Bowel Disease. Mediators Inflamm. 2017; 2017:4810258. https://doi.org/10.1155/2017/4810258. [PubMed]

26. Reinecker HC, Steffen M, Witthoeft T, Pflueger I, Schreiber S, MacDermott RP, Raedler A. Enhanced secretion of tumour necrosis factor-alpha, IL-6, and IL-1 $\beta$ by isolated lamina propria mononuclear cells from patients with ulcerative colitis and Crohn's disease. Clin Exp Immunol. 1993; 94:174-81. https://doi.org/10.1111/j.1365-2249.1993.tb05997.x. [PubMed]

27. Isaacs KL, Sartor RB, Haskill S. Cytokine messenger RNA profiles in inflammatory bowel disease mucosa detected by polymerase chain reaction amplification. Gastroenterology. 1992; 103:1587-95. https://doi.org/10.1016/0016-5085(92)91182-4. [PubMed]

28. McGee DW, Vitkus SJ, Lee P. The effect of cytokine stimulation on IL-1 receptor mRNA expression by intestinal epithelial cells. Cell Immunol. 1996; 168:276-80. https://doi.org/10.1006/cimm.1996.0076. [PubMed]

29. Aveleira C, Castilho A, Baptista F, Simões N, Fernandes C, Leal E, Ambrósio AF. High glucose and interleukin-1 $\beta$ downregulate interleukin-1 type I receptor (IL-1RI) in retinal endothelial cells by enhancing its degradation by a lysosome-dependent mechanism. Cytokine. 2010; 49:27986. https://doi.org/10.1016/j.cyto.2009.11.014. [PubMed]

30. Coccia M, Harrison OJ, Schiering C, Asquith MJ, Becher B, Powrie F, Maloy KJ. IL-1 $\beta$ mediates chronic intestinal inflammation by promoting the accumulation of IL-17A secreting innate lymphoid cells and CD4(+) Th17 cells. J Exp Med. 2012; 209:1595-609. https://doi.org/10.1084/jem.20111453. [PubMed]

31. Valatas V, Bamias G, Kolios G. Experimental colitis models: insights into the pathogenesis of inflammatory bowel disease and translational issues. Eur J Pharmacol. 2015; 759:253-64. https://doi.org/10.1016/j.ejphar.2015.03.017. [PubMed]

32. McKaig BC, McWilliams D, Watson SA, Mahida YR. Expression and regulation of tissue inhibitor of metalloproteinase-1 and matrix metalloproteinases by intestinal myofibroblasts in inflammatory 
bowel disease. Am J Pathol. 2003; 162:1355-60. https://doi.org/10.1016/S0002-9440(10)63931-4. [PubMed]

33. Fiocchi C. Inflammatory bowel disease: etiology and pathogenesis. Gastroenterology. 1998; 115:182-205. https://doi.org/10.1016/S0016-5085(98)70381-6. [PubMed]

34. Manicone AM, McGuire JK. Matrix metalloproteinases as modulators of inflammation. Semin Cell Dev Biol. 2008; 19:34-41. https://doi.org/10.1016/j.semcdb.2007.07.003. [PubMed]

35. Liu H, Patel NR, Walter L, Ingersoll S, Sitaraman SV, Garg P. Constitutive expression of MMP9 in intestinal epithelium worsens murine acute colitis and is associated with increased levels of proinflammatory cytokine Kc. Am J Physiol Gastrointest Liver Physiol. 2013; 304:G793-803. https://doi.org/10.1152/ajpgi.00249.2012. [PubMed]

36. Drygiannakis I, Valatas V, Sfakianaki O, Bourikas L, Manousou P, Kambas K, Ritis K, Kolios G, Kouroumalis E. Proinflammatory cytokines induce crosstalk between colonic epithelial cells and subepithelial myofibroblasts: implication in intestinal fibrosis. J Crohns Colitis. 2013; 7:286-300. https://doi.org/10.1016/j.crohns.2012.04.008. [PubMed]

37. Pedersen G, Saermark T, Kirkegaard T, Brynskov J. Spontaneous and cytokine induced expression and activity of matrix metalloproteinases in human colonic epithelium. Clin Exp Immunol. 2009; 155:257-65. https://doi.org/10.1111/j.1365-2249.2008.03836.x. [PubMed]

38. Koelink PJ, Overbeek SA, Braber S, Morgan ME, Henricks PA, Abdul Roda M, Verspaget HW, Wolfkamp SC, te Velde AA, Jones CW, Jackson PL, Blalock JE, Sparidans RW, et al. Collagen degradation and neutrophilic infiltration: a vicious circle in inflammatory bowel disease. Gut. 2014; 63:578-87. https://doi.org/10.1136/gutjnl-2012-303252. [PubMed]

39. Landy J, Ronde E, English N, Clark SK, Hart AL, Knight SC, Ciclitira PJ, Al-Hassi HO. Tight junctions in inflammatory bowel diseases and inflammatory bowel disease associated colorectal cancer. World J Gastroenterol. 2016; 22:3117-26. https://doi.org/10.3748/wjg.v22.i11.3117. [PubMed]

40. Munkholm P, Langholz E, Hollander D, Thornberg K, Orholm M, Katz KD, Binder V. Intestinal permeability in patients with Crohn's disease and ulcerative colitis and their first degree relatives. Gut. 1994; 35:68-72. https://doi.org/10.1136/gut.35.1.68. [PubMed]

41. Marin ML, Greenstein AJ, Geller SA, Gordon RE, Aufses AH Jr. A freeze fracture study of Crohn's disease of the terminal ileum: changes in epithelial tight junction organization. Am J Gastroenterol. 1983; 78:537-47. [PubMed]

42. Gibson PR. Increased gut permeability in Crohn's disease: is TNF the link?Gut. 2004; 53:1724-25. https://doi.org/10.1136/gut.2004.047092. [PubMed]

43. Fawley J, Gourlay DM. Intestinal alkaline phosphatase: a summary of its role in clinical disease. J Surg Res. 2016; 202:225-34. https://doi.org/10.1016/j.jss.2015.12.008. [PubMed]

44. Bilski J, Mazur-Bialy A, Wojcik D, Zahradnik-Bilska J, Brzozowski B, Magierowski M, Mach T, Magierowska K, Brzozowski T. The Role of Intestinal Alkaline Phosphatase in Inflammatory Disorders of Gastrointestinal Tract. Mediators Inflamm. 2017; 2017:9074601. https://doi.org/10.1155/2017/9074601. [PubMed]

45. Ziambaras T, Rubin DC, Perlmutter DH. Regulation of sucrase-isomaltase gene expression in human intestinal epithelial cells by inflammatory cytokines. J Biol Chem. 1996; 271:1237-42. https://doi.org/10.1074/jbc.271.2.1237. [PubMed]

46. Moran GW, O’Neill C, Padfield P, McLaughlin JT. Dipeptidyl peptidase-4 expression is reduced in Crohn's disease. Regul Pept. 2012; 177:40-45. https://doi.org/10.1016/j.regpep.2012.04.006. [PubMed]

47. Nicklin MJ, Hughes DE, Barton JL, Ure JM, Duff GW. Arterial inflammation in mice lacking the interleukin 1 receptor antagonist gene. J Exp Med. 2000; 191:303-12. https://doi.org/10.1084/jem.191.2.303. [PubMed]

48. Le Maitre CL, Freemont AJ, Hoyland JA. The role of interleukin-1 in the pathogenesis of human intervertebral disc degeneration. Arthritis Res Ther. 2005; 7:R732-45. https://doi.org/10.1186/ar1732. [PubMed] 